University of Louisville

ThinkIR: The University of Louisville's Institutional Repository

Electronic Theses and Dissertations

$12-2004$

\title{
The heart of the matter : the gendered relationship of altruism and marital happiness.
}

Natalie Jane Brinton Call 1978-

University of Louisville

Follow this and additional works at: https://ir.library.louisville.edu/etd

\section{Recommended Citation}

Call, Natalie Jane Brinton 1978-, "The heart of the matter : the gendered relationship of altruism and marital happiness." (2004). Electronic Theses and Dissertations. Paper 198.

https://doi.org/10.18297/etd/198

This Master's Thesis is brought to you for free and open access by ThinkIR: The University of Louisville's Institutional Repository. It has been accepted for inclusion in Electronic Theses and Dissertations by an authorized administrator of ThinkIR: The University of Louisville's Institutional Repository. This title appears here courtesy of the author, who has retained all other copyrights. For more information, please contact thinkir@louisville.edu. 
THE HEART OF THE MATTER:

THE GENDERED RELATIONSHIP OF ALTRUISM AND MARITAL HAPPINESS

\author{
By \\ Natalie Jane Brinton Call \\ B.S., Brigham Young University, 2000
}

\begin{abstract}
A Thesis
Submitted to the Faculty of the

Graduate Schoot of the University of Louisville

In Partial Fulfillment of the Requirements

For the Degree of
\end{abstract}

Master of Arts

Department of Sociology

University of Louisville

Lotisville, Kentucky

December 2004 
THE HEART OF THE MATTER:

THE GENDERED RELATIONSHIP OF ALTRUISM AND MARITAL HAPPINESS

$$
\text { By }
$$

Natalie Jane Brinton Call

B.S., Brigham Young University, 2000

A Thesis Approved on

November 24, 2003

By the following Thesis Committee:

Thesis Director 


\section{DEDICATION}

This thesis is dedicated to my husband

Jefferson Roberts Call

for his amazing example and his loving support and encouragement that has been essential to this work. 


\section{ACKNOWLEDGEMENTS}

I thank the many individuals whose support has made this project possible. I thank my committee chair, Dr. Karen Christopher, for her patient support and guidance, committee members, Dr. Allen Furr and Dr. Nancy Potter, for their excellent feedback and encouragement, and my father Dr. Eliot Brinton for numerous editing and analytical suggestions. I am grateful to my parents, Eliot and Bethany Brinton, and my in-laws, Jerry and Eldona Call, for wonderful, loving support during the project, and to many friends who kindly cared for my children during my graduate schooling: Nicole Beckstrom, Megan Gillespie, Becky Kjar, Cassandra Kraig, Kym Rangitsch, Alison Russell, and Waveney Taylor. I am deeply indebted to my husband, Jeff Call, for his altruistic love in our celestial marriage, and to our children, Naomi and Brinton, for their willingness to put up with the rigors of my schooling. Finally, I must acknowledge God as my ultimate source of inspiration and support throughout my educational pursuits. 


\begin{abstract}
THE HEART OF THE MATTER:

THE GENDERED RELATIONSHIP OF ALTRUISM AND MARITAL HAPPINESS
\end{abstract}

Natalie J. B. Call

December 16, 2004

In light of western cultural trends toward individualism, the presence of altruistic marital attitudes and behavior is examined as a predictor of marital happiness. Most quantitative studies exploring correlates of marital happiness use the same underlying concept of asking participants how their spouses' actions help them obtain marital happiness. Specifically, this research departs from convention by using a respondent's own level of altruism to predict his or her own marital happiness. Quantitative data gathered in the Louisville Metropolitan Survey 2004 is used for the project. Several methods of analysis find support for ties between certain manifestations of marital altruism and increased levels of marital happiness. Altruism is used as a predictor for both male and female achievement of marital happiness, which extends an expectation long held for women to include men. Different pathways between the independent variables lead to marital happiness for women and men, although altruism is found to be an important predictor for both men and women. Possible reasons for these gender differences are explored. 


\section{TABLE OF CONTENTS}

PAGE

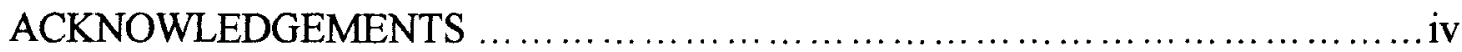

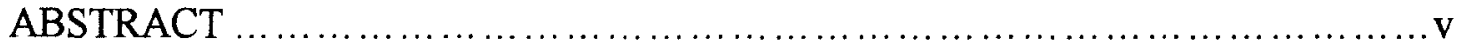

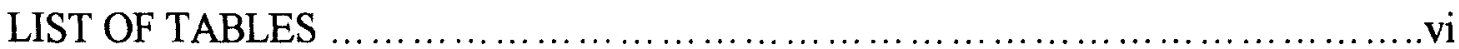

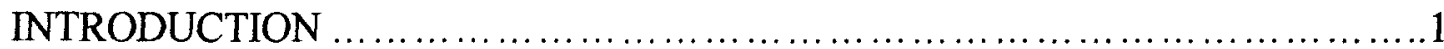

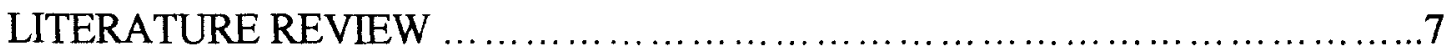

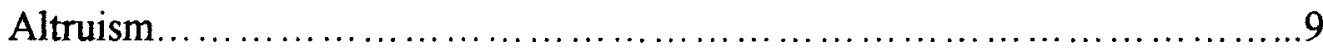

Philosophy and Altruism............................................ 12

Altruism in the Social Sciences........................................13

Theoretical Frameworks.................................................... 16

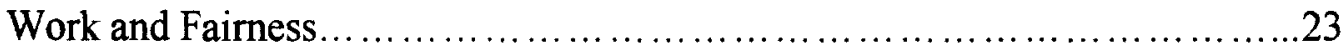

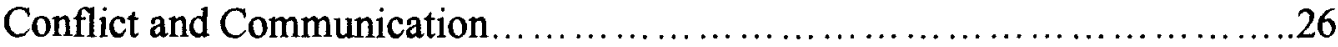

Self-Influence on Outcome of Marital Happiness............................28

Economic Resources.................................................. 29

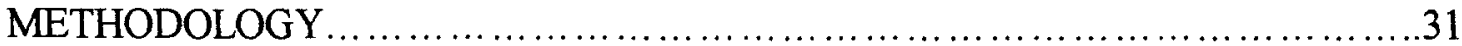

Operationalization of Variables............................................ 31

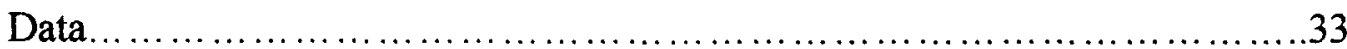

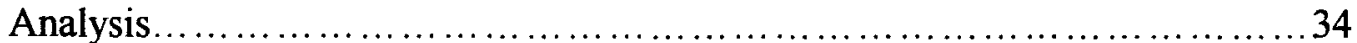

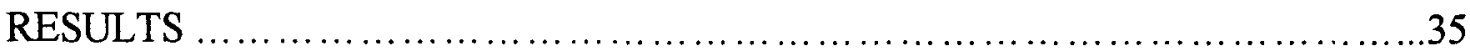

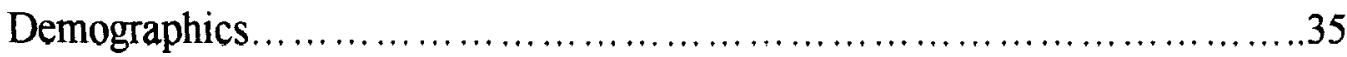

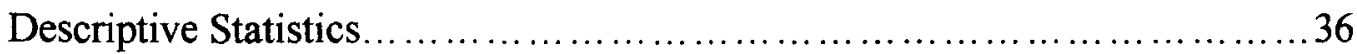


Regression.

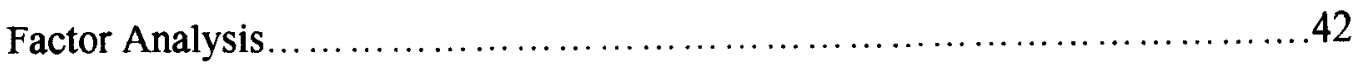

Path Analysis.......................................................... 44

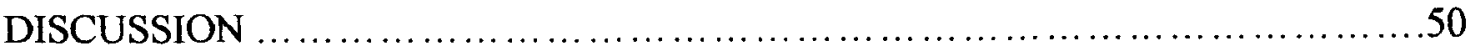

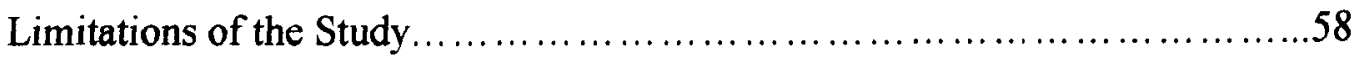

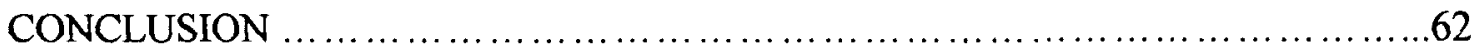

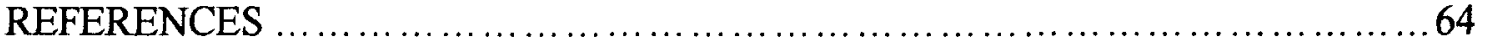

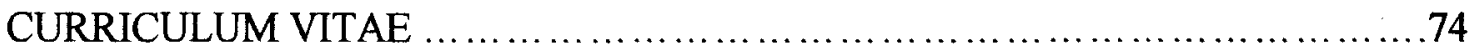




\section{LIST OF TABLES}

TABLE

PAGE

1. Descriptive. Statistics for Men and Women 39

2. Hierarchical Regression of Marital Happiness for Men 40

3. Hierarchical Regression of Marital Happiness for Women .40

4. Multiple Regression of Marital Happiness for Men 41

5. Multiple Regression of Marital Happiness for Women .41

6. Factor Analysis for Women .43

7. Factor Analysis for Men .44

8. Direct and Indirect Effects on Marital Happiness for Women .48

9. Direct and Indirect Effects on Marital Happiness for Men 49 


\section{INTRODUCTION}

Given the widely held human goal of attaining happiness, research on marriage and family relationships as a key to the success of that goal has become a prominent subset in the arena of social science research. This paper seeks to develop an understanding of marriage relationships, and specifically the outcome of marital happiness, in terms of a combination of external societal forces and choices made by the spouses within the relationships. Conflicting influences in Western society that affect marriages include the capitalist-based trend toward individualism and self-interest, which stands in opposition to more traditional orientations for interpersonal relations, such as the Golden Rule. Although individualism seems to be the more prevalent trend in modern society, the connection between marriage, a traditional institution, and conventional belief systems remains strong.

Marriage, one of the most fundamental contractual relationships in society, is also one of the most complex and difficult to characterize, even by the parties within the relationship. Much time and money goes into the research, therapy, and literature aimed at improving marriages and helping people find the successful ways of functioning in that relationship. However, divorce rates for first marriages remain as high as $40 \%$, many people now avoid marriage altogether, and dissatisfaction is common among those who stay married (Risch, et al., 2003). A question worth asking concerning the health of marriages is: How can we understand marriage today in the context of the current social 
environment? What cultural trends influence marriage function and how are those influences incorporated into the way marital well-being is defined? Do such trends change the way that married individuals experience love and happiness in marriage? In current American views, expectations of marital satisfaction seem to hinge at least partly on a "quid pro quo" relationship, where each person in the relationship "must receive from the other after having given something" (Everett, ed., 1992). An examination of popular marriage and family therapy materials offers insight into this matter, in the way such manuals describe different relational theories as they apply to marriage relationships. The authors hypothesize a variety of underlying causes for success or the lack thereof in a marriage, from psychosis of the relationship to solutionfocused understanding (Nichols \& Schwartz, 1998). However, many of these approaches bring an innately self-centered approach to the question of what makes a marriage satisfying. For example, with the concept of "accommodation", instead of an individual focusing on trying to work in the best interest of his/her spouse, the idea centers on the individual pressuring the spouse to accommodate to his/her wants (Nichols \& Schwartz, 1998).

In observing the dominant messages of current American culture, much of society now views love as an instrument of self-fulfillment instead of a binding tie that serves to regulate selfish behavior within a relationship. At best, the highest cultural expectations for relational giving expect unselfish action when the personal cost incurred is not too great. A reconceptualization of happiness, love, and marital costs and rewards would provide a grounds for understanding consideration for the other as beneficial for the relationship, as well as both marriage partners individually. Currently in study and 
discussion of motherhood and marriage the assumption that service for the child or spouse somehow detracts from the gains of the self has gained prominence. In contrast to these scientific perspectives, insightful authors, researchers, and religious figures call for an understanding of self that is rooted in the relationships cultivated with friends and family. Arguably any conceptualization of self-ness is based on comparison to others and thus largely contextual in nature. In his discussion of the nature of marital relationships and happiness, A. Scott Loveless describes Russian author Tolstoy as portraying "the relational aspect of our nature - the very dimension of our lives that is vital to happiness" (Loveless, 2001, p.1).

Few theorists propose that people find greater personal and marital satisfaction by focusing more on loving their spouse than if they look for happiness based on receipt of love from their spouse. Wendell Berry writes that relationships within the home should be based on trust and understanding and he describes "marriage as a state of mutual help"(Berry, 1990). He suggests that in contrast to prevailing conflicts over rights and benefits between married individuals, some couples "understand themselves as belonging to their marriage, to each other ... What they have they have in common, and so, to them, helping each other does not seem merely to damage their ability to compete against each other" (Berry, 1990). He ironically asserts that the very people who are willing to slave for bosses that they do not love balk at the thought of freely serving those they do love.

C. Terry Warner details methods for being honest with oneself, which results in more honest and enjoyable relationships in his book The Bonds that Make Us Free: Healing Our Relationships, Coming to Our Own. Although many such books that suggest being honest in relationships are not advocating a more intimate and loving 
relationship, this is what Warner proposes. He purports that by being honest with themselves, individuals can come to the accurate conclusion that they need to change their own faults to interrupt negative cycies and possibly change the entire relationship.

His theory is based on the idea that by being true to themselves, people are "freed" to be their true and loving selves in their relationships with others. This freedom from negative cycles of behavior and expectations that are hinged on someone else's choices brings greater happiness to married individuals. Such attitudes and ideologies in marriage would be manifest by an individual's degree of attentiveness to his or her spouse's needs, without basing happiness in the relationship on reciprocating gestures.

In the typical approach to marital satisfaction individuals are asked to rate different issues such as finances, intimacy, time spent together, children, and communication in terms of how much agreement on the issues exists between spouses or whether or not the individual views the issues as problematic within the marriage (Risch, et al., 2003). The current paper suggests that while these issues may be important in determining marital satisfaction or success, something more fundamental should be examined. A theory of marital happiness based on altruistic love and behaviors requires not only a shift in explanatory paradigms, but a change in the way marriages are examined as well. Although the theory is based on the idea that marital behavior will be observably different in the presence of an altruistic orientation, therefore influencing marital happiness, the attitude behind the selfless behavior of the altruist is as important to the outcome as the actions are. Going beyond the idea of expecting selfless behavior to involve the precedence of the spouse's needs over the individual's, this theory proposes that when the individual acts conscientiously to become him/herself completely, 
the previous barriers to warmth and happiness in the relationship erode to allow loving and giving in a complete sense. This change within individuals frees them from keeping score in the marriage and allows them to feel greater satisfaction in the reiationship, because their feelings are based on what they themselves control. Although such an approach may seem to regress toward the inequalities of marriage typical of past eras, it can be applied equally to husbands and wives. Furthermore, the interpretation of the meanings behind marital behaviors becomes quite different. In addition to this difference in explanation and outcome associated with altruistic behavior in marriage, this paper proposes that the altruistic model will be applicable for men as well as women. It should be noted that this characterization of the dynamics of marital relationships does not apply in relationships characterized by abuse, where it is obviously not advisable for individuals to cooperate with the abuse, rather to seek help and remove themselves from the relationship.

Although many avenues have been explored in terms of measuring individuals' satisfaction in their marriages, an essential shift in focus may be needed to allow for better understanding of the concept of marriage. The much accepted attitude of putting oneself first is not expected to yield happiness in the marriage setting. Manifestations of altruistic love are expected to predict marital happiness for both men and women. Typically other-oriented service has been studied as an element of marital behavior more often encouraged and found in women. In contrast, this research looks at altruism in the marital orientations of both men and women. Therefore, an approach to measuring marital satisfaction that resounds more closely with the communal nature of marriage would involve individuals rating the success of their marriages based on how well they 
selflessly serve their spouses. A central question to this examination is: how well can marital satisfaction be predicted by studying the ways that married individuals focus their attention on selflessly meeting the needs of their spouses? 


\section{LITERATURE REVIEW}

Given the universal desire for happiness and the unsurpassed potential of marriage to provide happiness or its opposite, the marriage relationship is a natural focus of social science research. Previous research has confirmed the connection between marital happiness and general life happiness for married individuals (Glenn, 1981; Schluterman, 2001). This research found that more than any other elements of life, marital satisfaction influenced total satisfaction. The overwhelming majority of Americans, “over $90 \% \ldots$ identify 'having a happy marriage' as one of the most important" life objectives (Schluterman, 2001: 1). Thus the study of marriage and the ways in which couples find happiness through that relationship is vital in a society where most adults will be married at some point in their lives.

Marriage is a relationship that requires compromise, caring, serving, and a concern for someone else's needs. The broad picture in which marriages operate is one characterized by individualism and capitalism in western society. As Arnett asserts, "the dominant ideology of the American majority culture at the present time is individualism ..." that results in "self-fulfillment and self-esteem rank[ing] far higher on the scale of values ... than self-restraint or self-denial" (1995: 624). Consequently the competition between self and other is a view "quite widely endorsed in Western culture" (Wood, $p$ 109). Bellah et al. describe the result of this cultural trend saying "we Americans believe 
in the self" (Bellah, et al., 1996: 90). In the book Habits of the Heart, individualism is associated with what the authors term a "therapeutic attitude." This term is defined in the statement "the therapeutic attitude reinforces the traditional individualism of American culture, including the concept of utilitarian individuals maximizing their own interests, but stresses the concept of expressive individuals maximizing their experience of inner psychic goods" (Bellah, et al., 1996: 104). Interestingly, these researchers find that even Americans who do not intend to embrace individualism are influenced by it, writing "in the middle-class members of America's mainstream, we found therapeutic language very prevalent, even among those who also retain attachment to other modes of thinking about and experiencing the world" (Bellah, et al., 1996: 109).

True caring and willingness to give preeminence to the needs of the relationship and one's spouse have traditionally been associated with successful marriage relationships. These skills have been feminized in capitalist culture and yet, historically speaking, religions and cultures across the world have proclaimed and endorsed some form of the Golden Rule, with application expected for both men and women. Many caution that the trend to forget such motivations in business and family behavior, damages the quality of relationships, as well as the ability for individuals and society to achieve happiness. "Given Western culture's prevailing emphasis on self-interest and individual, independent identity, the capacity to let go of egocentrism is particularly difficult to learn and to practice" (Wood, p 109). The association between caring feelings and behavior with the women's sphere of home and family has damaged the credibility of such an orientation in a market driven, dollar obsessed society. "Many of the concrete activities that comprise taking care of others are defined as less valuable than tasks that 
assume and enhance self-interest and individual achievement" (Wood, p 116). Applying this social trend to the context of marriage, how has the low status of caring, altruistic behavior affected the relationship between loving attitudes and behaviors and the outcome of marital happiness?

In this research it is hypothesized that in spite of the societal influence of individualism, married individuals who embrace a caring orientation within their marriages will still demonstrate marital happiness as a result of their focus on the concerns of the other. This hypothesis rests on the belief that such caring increases feelings of self-worth in the carer, fosters greater feelings of love and concern for the recipient of the service, and brings joy in contributing to the happiness of the other. As a pleasant side effect, often such behavior is reciprocated by the other spouse, leading to a positive cycle of emotion and behavior within the marriage. This outcome, however, must not be the focus or rationale for the behavior, because it then is no longer altruistic at its core, and any lack of reciprocity will then break the positive cycle. Choosing to care in such a way and acting on those feelings may also be incidentally empowering and invigorating to the individual, not a means of losing self-identity as commonly feared in western society.

\section{Altruism}

Varying connotations exist for the term altruism, with many of the modern associations being negative. Some have even gone as far as defining altruistic behavior as action that benefits another and harms the self. In recent years, Piliavin and Charng note in a review of altruism in social science literature that there appears to be a shift 
away from the jaded assumption that altruistic behavior must in fact contain hidden "egoistic motives" (1990: 27).

One common misconception about altruistic love is that the self is diminished or even destroyed by such an orientation (Wilson, 1975). However many researchers of altruism have found that one facet of an altruistic belief system is the understanding of the equality of humankind (Piliavin \& Charng, 1990; Monroe, 1996; Post, Underwood, Schloss, \& Hurlbut, 2002). This characteristic of altruistic persons suggests that the capacity to love and care for others unselfishly may stem from a deeply rooted sense of the value of oneself as well as all other humans. Individuals who respect others in this way seem capable of putting others first because they do not harbor fears of insecurity and competition in relationships. With such an interpretation of altruistic giving, it follows that equality and respect would be more likely for both individuals in the marriage, although these aspects of the relationship are not explicitly studied in this research. This understanding of the results of altruism addresses the concern that individuals, especially women, who behave altruistically in their marriages may lend themselves to being underappreciated and taken advantage of in the relationship.

Reciprocity is not a demand of altruistic behavior, which engenders concern about the practice of altruism from scholars and writers who view equality or fairness as a prerequisite for marital well-being. Although mutual altruism between spouses represents the most complete type of marital giving, an individual acting altruistically in marriage will not focus on the existence or presence of altruistic behavior in his or her spouse. Instead, trust in the goodness of the spouse, an altruistic attitude, will allow such an individual to be freed from self-interest in the marriage. Unfortunately due to the 
constraints of the survey this research is based on, trust in marriage is not explored as a manifestation of marital altruism. Because of the additional survey limitation of interviewing only one individual of each couple, the correlates of mutual altruistic love are left for future examination. For present purposes, the existence of altruism in the marital focus of individuals is of sufficient importance and impact to merit study on its own.

In contrast to the negative associations with altruism delineated previously, altruistic love in marriage can be described as desires and behavior enacted with the needs and happiness of one's spouse as the paramount motive. If the motivational element of altruism is the focus of the definition, "altruistic behavior must benefit another person, must be performed voluntarily, must be performed intentionally, ,.. must be performed without expecting any external reward" and the benefit of the recipient must be the goal of the behavior (Bar-Tal, 1985: 5). This definition captures the essential elements of altruism without assuming that damage to the giver is inherent. Indeed, in one study, Kerber (1984) "found that people high in altruism saw helping situations as more rewarding and less costly than did people low in altruism" (Piliavin \& Charng, 1990). This suggests that non-altruists are likely to possess a more negative view of altruistic behavior than those who practice altruism.

Such altruism involves the ideal of caring for another, which Wood defines as incorporating responsiveness, sensitivity to others, acceptance, and patience. These elements of caring rest upon the ability and willingness to "let go of ... preoccupation with oneself and one's own concerns" (Wood, 1994: 108). Literature on caring and other 
such motivations for action in personal relationships often focuses on caregiving for dependent persons, such as children, not a relationship between equals.

\section{Philosophy and Altruism}

Many philosophers have occupied their writings with concerns of the moral nature of varying orientations between self and other. Although they seldom reference the context of marital relationships, the philosophies they expound are particularly apt in such a context. Philosophical concern with the term altruism began with the origination of the term in Comte's conceptualization of the opposition of egoism and altruism (Loveless, 2000: 53). Many works in the philosophical tradition also describe such behavior and motivations, using alternative terminology instead of altruism, such as Soren Kierkegaard's Works of Love (1962). One example of the exploration of altruism that is thoroughly pursued in philosophy is the relationship between self and other, with discussion of obligations, reciprocity, giving, and sacrifice. Satre hints at complexities of the self-other relationship that engender conflict: "While I attempt to free myself from the hold of the Other, the Other is trying to free himself from mine; while I seek to enslave the Other, the Other seeks to enslave me ..." (Sartre, 1956: 364). This cycle of entanglement is broken by the altruist, who seeks happiness for the other and therefore enters into partnership instead of competition.

As Levinas (1969) writes of living and even being for the other, he offers a glimpse of the wholeness that an individual can attain through altruistic living. Buber's (1970) depictions of the outcomes of self and other orientations further illustrate the futility of seeking happiness through attainment of self-centered goals. He advocates life 
in a "world of relation" where "man finds guaranteed the freedom of his being and of being" a freedom that comes from shedding preoccupation with self (Buber, 1970: 100). Altruism in the Social Sciences

"Altruism is not ... an agreeable ornament to social life, but it will forever be its fundamental basis. How can we really dispense with it?" (Durkheim, 1933: 228). Notwithstanding the pre-eminence given to altruism in the preceding quote from one of the founding voices of sociology, little attention has been paid to the influence of altruism in sociological literature of late. Although feminists including Nancy Folbre and Paula England have expanded the discourse surrounding care and related topics in recent years, most research and writing that explores altruistic motivations and behavior still fails to investigate those issues in the context of marriage.

In spite of a rich philosophical tradition around the concept of altruism, few social science studies have investigated the idea. Research on marital altruistic love is even more rare in the recent literature than other explorations of altruism. Although a few sociologists in the early and mid-twentieth century wrote about altruism in the context on marriage, interest in studying it diminished over the later half of the century, possibly because of difficulties surrounding measurement (Buerkle \& Badgley, 1959, Buerkle, Anderson, \& Badgley, 1961, Levinger, 1965). The early research attempts at measuring altruism and marriage relied on instruments that offered hypothetical situations where the spouse's needs were pitted against one's own needs. This approach, based on response to the hypothetical, was found to be ineffective for measuring people's altruistic tendencies. In addition to such early measurement problems, the rising tide of individualism as a force in society has influenced the lack of interest in the study of altruism as well. 
Although decades ago Friedrichs lamented the lack of attention given to altruism in the social sciences, stating it "has received almost no systematic attention from writers in the mainstream of contemporary sociology or social psychology," the situation has been far from remedied in the past forty years (1960: 496).

Economic views of the principle of altruism have little bearing on the current study, as they model altruism as a rational function based on the utility of giving benefit to the other at a certain time. Although such researchers write of altruism, the phenomenon they describe is not akin to a motivation that promotes the well-being of another and derives its foundations from love. Becker $(1980,1981)$ and others who depict altruism in this manner seek to justify the existence of altruism as a form of behavior, and yet they display a disregard or lack of understanding for the element of humanity that separates altruism from more market based principles.

Ammons and Stinnett offer findings that lend strength to the theory of altruistic marital happiness, describing that ''otherness' rather than 'selfness' contributes to each partner's emotional well-being and personal growth" (1980:39). This orientation in relationships, specifically marriage, represents "a qualitatively different form of motivation, motivation with an ultimate goal of benefiting someone else" as proposed by Batson and Shaw (1991: 107). Repeatedly, marriage research describes this motivation to benefit the other as incompatible with natural desires of the self, which are assumed to follow ideals of personal freedom.

One recent study that examined noncontingent giving within marriage surveyed married couples and asked them to identify ideal marital norms. After finding that almost all of the couples, regardless of how long they had been married, selected the communal 
form of marital giving as the ideal, the researchers asked the participants to described which of the norms most closely fit their own marital interaction patterns (Clark, Graham, \& Grote, 2002). Again, most couples in the study indicated that the norm that they most closely followed was the communal norm. The researchers also found, however, that couples were likely to veer away from implementation of that norm at times when their needs were not being met (Clark, Graham, \& Grote, 2002). Although this research has some value, much of the strength of the findings is undercut by the likelihood that the participants were biased in their self-reports of living close to their ideal within their marriage relationships. A research design such as the one employed by Hochschild in her study The Second Shift, would be preferable for addressing such research questions because the perspective of the researcher could help to balance a selfreport.

In his dissertation, Loveless boldly proposes that three types of marital love will produce three types of happiness, with varying degrees of salience (Loveless, 2000). The typology he develops includes hedonistic love, individualistic love, and altruistic love. Hedonism involves seeking love in any manner possible and equates wrong only with those things that impair pleasure. In contrast, individualism often incorporates boundaries for pleasure-seeking and places primacy on attainment of goals and desires. Altruism shifts the focus of motivation from the self to the other and altruistic love revolves around the needs and happiness of those outside the self. His study uses qualitative interview techniques to study the ways in which couples find what they experience as happiness in their marriages. This in-depth method allows for understanding of not only those elements of marital life that the married individuals 
themselves are cognitively aware of, but for the researcher to explore topical themes that emerge in the interviews as well.

One way in which altruistic behavior in marriage is expected to yield greater marital happiness for the giver is suggested by the idea that "outside the market framework, the benefits of service ... redound to the server as well as to the served" (Ahlander and Bahr, 1995: 65). Such love can be explained using a typology for benevolent love, including the elements of "prudence, temperance, fortitude, justice, and charity" (Jeffries, 2000: 234). This is manifest in loving relationship behavior, such as a willingness to settle disagreements with calm discussion, the ability to give, and the desire to put the needs of the other and the relationship ahead of incompatible personal desires (Jeffries, 2000: Bjornberg, 2004).

\section{Theoretical Frameworks}

Hochschild (1983) covers many facets of interpersonal relationships in her theoretical work, which springs from the critical feminist tradition. In her book, The Managed Heart, she sets forth the concept of "emotion work" as the struggle to portray an emotion that you do not feel, but is required by a role you play. In the study that forms the basis of the book, Hochschild examines the effects of "emotion work" on front line service industry workers. She explains that people who perform this "emotion work" within the context of paid labor often experience greater cognitive dissonance and emotional drain than other workers. This concept has direct application in the understanding of marriage, where performing service for a spouse without love as the motivating factor is more likely to cause resentment than happiness within the marriage. I would expect problems to occur in marriages where individuals are trying to act in a 
self-sacrificing way, but their emotions and motives are not aligned with those actions, which would cause strain on the relationship. "Emotion work" would serve as a basis for understanding the downward spiral of unmet expectations, disappointment, and accusations that cause spouses to feel criticized and unappreciated. Conversely, individuals who are grounded in a more altruistic approach to their marital behavior are less likely to experience such role strain, which increases their ability to experience marital happiness.

The present research builds on an element of Weber's theoretical works, in his concern for loss of meaning in a rationalized society (Ritzer and Goodman, 2004). One manifestation of the search for meaning within our capitalist society would be the attainment of marital happiness through loving service to one's spouse. Arnett (1995) asserts that through participation in the requisite role expectations for married men and women, marriage provides a source of meaning for individuals. Another facet of Weber's sociology that could be utilized in a framework for understanding these data is his depiction of the irrational results of rational behavior. When rationalization is applied to individual marriage relationships, important elements such as love and subjectivity would be replaced by efficiency, predictability, and calculability. This indicates that a focus on less rational means in marriage, such as altruism, would be more likely to produce marital happiness.

Similarly, Adorno and Horkheimer also offer theory with useful application for analyzing the included research findings. In their work, Dialectic of the Enlightenment, they criticize the Enlightenment view that rationality yields free and autonomous actors (1972). Rational behavior, modeled from the Enlightenment and capitalist thinking in 
our society, when applied to marriage would yield entrapment, because a person's happiness hinges on reciprocity and behavior of their spouse that they cannot demand or guarantee. This theory provides an explanation for why married individuals would enjoy less marital happiness as a result of pursuing "enlightened," rational behavior than if they use tradition-based paradigms that encourages altruistic thinking and actions.

As critical theorists from the Frankfurt School, Adorno and Horkheimer have an ontological understanding of society as socially constructed. They question the idea of progressive society, as seen in their questioning of the Enlightenment assertion that modernization and rationality are necessarily leading to a better end (Horkheimer and Adorno, 1972). This interpretation of prevalent assumptions illuminates the arguments of this paper, in that through acceptance of Enlightenment philosophy, Western society may have regressed in terms of interpersonal relationships. Adorno and Horkheimer encourage society to self-reflect in order to deconstruct what we have taken for granted, such as the fundamental assumptions of capitalism, individualism, and rational action (Horkheimer and Adorno, 1972). Thus research on marriage should entail questioning the assumptions underlying the research questions, methods, and interpretations applied in the field, which is a fundamental purpose of this paper.

An additional possible theoretical approach with application in this analysis would be the perspective on power embraced by third wave feminists. Rather than viewing power as a zero-sum equation, where allocation of power in one area requires diminishment of power elsewhere, this feminist viewpoint offers that different parts of society can create and exercise power differently (Ritzer and Goodman, 2004). A feminist example of this would be the use of terminology to describe women as 
"survivors" of rape, rather than "victims," to signify the power they exercise in their own recovery process (Gagne, 2004). An application of such a theory to the current research provides a possible explanation for the complex balance of power in the mamage relationship. A traditional description of power in a marriage would use patriarchy as the basis for explaining the workings of the relationship. In contrast, the more complex understanding of power could allow for the interpretation of the choice to serve one's spouse without expectation of reciprocity, as an example of freeing oneself from the tyranny of unmet expectations and taking control over one's own happiness in the relationship. Although the marriage ideal involves mutual altruism between husband and wife, because a requirement for such behavior from another cannot be enforced, the expectation or demand of reciprocity is more likely to lead to frustration and unmet needs than is the implementation of giving of oneself in a truly free manner.

This call for altruism without demand for reciprocity requires further explanation, given the decades of feminist work towards achievement of greater power for women, within the home and workplace. The fight for gender equality in these spheres largely arose from the feminist awareness of the plight of women and children in the aftermath of divorce proceedings, where women who were wholly devoted to husbands and children in their marriages become the most vulnerable. In her discussion of divorce, Crittendon quotes law professor Ann Laquer Estin, "Within the law, there is a remarkable disregard for caregiving - the norms of nurturance, altruism, and mutual responsibility that are usually thought to characterize family life ... [are] almost entirely irrelevant when courts resolve the financial incidents of divorce" (Crittendon, 2001:138-139). Societal changes are obviously needed; however, demand for equality between women and men seems to 
threaten further division between male and female perspectives on the issue and to possibly degrade the very cause being advanced. Changing the way in which capitalist Western society values nurturant behavior and values requires action on many levels, including restructuring public policy, legislation, financial reward systems, education, and interpersonal relationships. Attention focused on producing change in institutions and policies will eventually be reflected in the lives of members of society. Altruistic behavior as described here, does not involve self-abnegation, indeed such an orientation cannot produce a fully caring outcome (Loveless, 2000). Rather, altruism incorporates appropriate boundaries for respecting and fulfilling what are truly the needs of others, rather than whims or desires.

Another important aspect of feminist scholarship that has application for this research is the study of marriage as a gendered experience and relationship. Feminist literature has proved the groundwork for understanding gender differences in the lived experiences of husbands and wives, largely because history and current social expectations have different influences on males and females. Investigating the similarities and variances in the men and women of the sample allows for exploration of the cultural meanings behind the findings.

A symbolic interactionist perspective offers insight into the process of creating shared meanings, whether the symbols being studied are shared by an entire society or even if they are the product of dyadic interactions. This framework also provides explanations for the cycles that occur in interpersonal relationships, in which individuals can act and react in a pattern of behavior that tends to replicate itself. These interactions establish a tone for happiness or dissatisfaction within a marriage and although both 
spouses participate in them, the patterns are likely to be altered by conscientious behavior on the part of either spouse.

Similarly, Burr describes a scenario that would influence marital well-being, stating "although most of us assume that our satisfaction in a relationship such as marriage is 'made' by the other person, this proposition states that a person (Ego) is more satisfied in a relationship when he or she is doing a good job of enacting the role in that relationship" (1973: 68). The current research does not specifically explore marital role expectations; however, given the greater role requirements generally allotted to wives in the context of marital relationships, this could explain a tendency for women to experience less marital happiness than men. Because of the complexity of the roles they engage in, women would be expected to have a harder time fulfilling the ideals of their role and therefore experience less marital happiness as a result.

Resource theories of marriage are rejected for this analysis on the basis of the understanding that such a conceptualization of marital interaction denies the potentially altruistic nature of the marriage relationship. As Kleingeld explains, "the model suitable for marriages is one of cooperation between individuals who recognize each other as equals in a shared pursuit, not a model of negotiation between rational economic agents maximizing their individual profit" (1998: 230). Although the genre of family research tends to depict marital happiness in terms of the actions of the other, certain research has focused more closely on an exchange or reciprocity framework for understanding marriage relations. Differing resource theories include exchange theory, equity theory, and equality theory (Clark, Graham, and Grote, 2002). Each of these theories applies economic market principles as an explanation for the workings of marital behavior and 
relationships. One of the biggest failings of such descriptions of marriage is the inherent assumption that marital interaction is often or always rationally based.

Most studies on marital happiness/satisfaction/quality focus on the ways in which one's spouse influences one's marital happiness. Although this is the established and somewhat intuitive direction of marriage research, the current study attempts to incorporate an alternate orientation to measuring facets of marital happiness. It explores the relationship between an individual's actions toward his or her spouse and that individual's sense of marital happiness. This understanding of marital happiness as largely influenced by one's own actions avoids becoming individualistic because it requires that the individual act in accordance with the need of the spouse. Such a theory of self-determined marital happiness is informed by philosophical writings, certain past research, popular relationship guidance literature, and informal observation.

In the past fifteen years of research on marriage, a vast body of literature has developed concerning itself with the outcomes of marital happiness, stability, and quality, as well as negative outcomes to marriage such as instability, abuse, and divorce.

Researchers measure conflict, communication, support, interaction, intimacy, sharing, expectations, power, interdependence and other elements within marriages as well as external factors that influence the relationship, including finances, alternatives to the relationship, family of origin, religion, parenthood, and careers. In an attempt to extend past research findings as well as take the field in new directions, this project focuses on work and fairness, self-influence of marital happiness, conflict and communication patterns, and other facets of marriage as they provide possible pathways between marital altruism and marital happiness. 
One of the most often explored topics within the realm of marriage research during the last two decades is the relationship between work and family life. With rising material expectations in western society, and the related increase in numbers of women employed outside the home, this topic naturally grew in popularity, with researchers seeking to understand the ways in which men and women seek balance between their work and home priorities. A subset of the work and family literature deals with the way in which household labor and caring is distributed among family members, specifically the marriage partners.

Women are most often the instigators of the struggle for fair distribution of family tasks, as traditionally such work has been their burden and continues to fall to them in spite of full time paid employment for many women. As a result of prevailing capitalist values, "much of the existing literature concerning the impact of women's work roles ... has assumed that the nature of housework is inherently isolating, restrictive, unskilled, repetitive, devalued, low in status, and consequently, not very rewarding" (Shehan et al., 1986: 407). Such literature set the stage for explorations of fairness in household labor and how this corresponds with the "complex and shifting social processes relation to the well-being of families, the construction of gender, and the reproduction of society" (Coltrane, 2000: 1208). After finding that many women were performing an unequal portion of housework, even if they were also involved in the paid labor force, but few reported an unfair division of labor, researchers investigated possible explanations for this perception. One framework derived from gender construction theories that exists to explain unperceived unfairness describes a "symbolic equation of housework and care ... 
[that can] encourage women to consider men's expressions of affection or positive intent as sufficient, thereby lowering their expectations and judging current unbalanced labor arrangements as fair" (Coltrane, 2000: 1224). Hochschild (1989) describes such a phenomenon as an "economy of gratitude" in which each spouse accepts choices by the other that are construed as symbolic offerings.

Many studies examine fairness as an intervening variable in the relationship between performance of household labor and marital satisfaction. Level of perceived fairness is associated with greater positive or negative marital well-being for women, but not for men (Rogers, 2000; Greenstein, 1996; Voydanoff \& Donelly, 1999). This stems from the traditional assignment of household tasks to women, who are likely to now embrace the ideas that such tasks are restrictive and burdensome.

In contrast to the mainstream constructions of unequal distributions of household labor as a relic of patriarchal oppression over women, Ahlander and Bahr $(1995,1996)$ point to the possible redeeming elements of the performance of housework. Bellah et al. (1985) also echoes the need to reconceptualize the meanings of work, saying "a change in the meaning of work and the relation of work and reward is at the heart of any recovery of our social ecology" (1985: 289). Along with other academics who question the assumption that traditionally female work is oppressive, they "suggest that most academic models of housework focus too much on individualism, conflict, and inequality and not enough on the spirituality and the positive aspects of moral obligation and service to family members" (Coltrane, 2000: 1215). They propose a shift in the way that family work is studied, taking "the study of family work beyond exchange or contractual 
obligations, and [making it] more compatible with a 'social covenant' orientation" (Ahlander \& Bahr, 1995: 64).

The call for such a shift comes in response to the notion of family division of labor, terminology which suggests competition and antagonism between family members. The concept of "shared participation in family life" resonates with the goals of unity and mutual growth that many families espouse (Ahlander \& Bahr, 1995: 65). Housework can become binding or divisive, depending upon the framework of interpretation and Bellah et al. suggests "we discover who we are face to face and side by side with others in work, love, and learning" (1985: 84). This state is achieved after overcoming "resistance to the moral obligations of family work, resistances associated with the personal search for freedom, autonomy, and self-satisfaction" (Ahlander \& Bahr, 1995: 61). One concern with this depiction of housework is that it seems to require joint participation in such activities. However, most marriages do involve joint, if unequal, engagement in household labor. Absence of mutual participation on all levels should not exclude the possibility that the housework can be viewed as a positive family experience.

Although much of the literature points to the importance of perceived fairness for workload distribution, for the purposes of this research a somewhat opposing view will be taken. It is predicted that existence of a fairly distributed workload will not be an important factor in marital happiness in this model. This position is taken, because an altruistically oriented individual would not be expected to experience a lack of happiness in a marriage with a seemingly unfair or distribution of work. Perception of equally shared work may yield increased levels of marital happiness, however this is not expected to be a significant factor in the model, 


\section{Conflict and Communication}

Study of marital communication and the ability to manage marital conflicts describes important influences on the outcome of marital happiness. Since "communication problems ... are the most frequent complaint of couples entering therapy," good communication abilities seem crucial to marital happiness (Burleson \& Denton, 1997: 884). Research on positive communication patterns is less prevalent than the literature on the results of inadequate communication. Although many academics and therapists tout the importance of good communication skills, the ability to communicate one's feelings in a relationship is not necessarily beneficial to the relationship if the message is negative. The underlying meaning of what is being communicated may influence marital happiness as much as the ability to clearly convey the message.

Conflict situations require the use of communication as well as coping strategies to manage, resolve, or diffuse the tension in the marriage. Marital conflict can be described as an interaction where "even while individuals are trying to influence others, those others are seeking to control the situation ..." (Cast, 2003: 185). Conflicts can arise as the result of sudden events or they can involve recurring strains over a period of time (Bowman, 1990). Interestingly, one study on conflict management and coping behaviors reports that "responsiveness to the emotional qualities of the relationship is more typical in happy marriages than is the use of cool, rational problem solving" (Bowman, 1990: 471). Although this finding is incidental to the purpose of the cited study, it has important possible implications for the present research.

Another study defines conflict as "a confrontation between individuals ... regarding scarce resources, incompatible goals, contested methods, or a combination of 
these" (Bjornberg, 2004: 35). Power and influence in the relationship are seen as central in determining whose needs prevail in a conflict situation. This depiction of relationality stands in contrast to a portrayal of relationships where "each partner gives and does not expect to be reciprocated and any kind of calculation is regarded as morally wrong. This kind of community focuses upon relational ethics and whatever is best for the relationship as such" (Bjornberg, 2004: 48). Additionally, "couples who do not compromise in their conflicts have low marital quality" (Jeffries, 2000:240).

Most research examining marriage, love, and happiness disregards the moral implications of love and the ways is which it should be expressed within the marriage context. The scientists write as if love is an emotion separate from the interactions and communications of the marriage. However, studies of long-term marriages find that such couples place emphasis on "kindness and understanding, are affectionate and altruistic, and are sensitive to the needs of the spouse" (Jeffries, 2000: 240).

Although feelings and expressions of gratitude seem to intuitively fit with marital love, especially altruistic love, the literature displays a curious lack of interest or research on the subject. In all the searches performed, gratitude was never used as a key topic in the marriage research. It is likely that certain studies on communication include gratitude as one facet of the study, however such research was not identified. Even a review of the comprehensive Handbook of Family Communication revealed no study of expressions of gratitude in marriage (ed. Vangelisti, 2004). Mention of "appreciation" given from one spouse to another was the most similar topic found in instruments in the Handbook of Family Measurement Techniques (Touliatos, Perlmutter, \& Straus, 1990). Again, the 
most frequent approach for that subject was also based on the experiences of the individual in terms of how much support she/he received from the spouse.

Self-Influence on Outcome of Marital Happiness

One vein of marriage research involves the notion of individuals influencing the outcome of their own marital happiness. Studies on the perceived responsibility for marital events suggest "that each person in the relationship tends to claim a greater contribution to an activity than the partner is willing to attribute to them" (Fincham \& Bradbury, 1989). Fincham and Bradbury's finding that egocentric bias for the responsibility for negative relationship events is positively linked to marital happiness supports the underlying theories of this paper. One explanation for such behavior is the altruistic attitude of excusing one's partner from culpability for negative events, while voluntarily shouldering the blame, both of which serve to cast one's partner in a more positive light than oneself. Another paper describes important aspects of marital commitment stating "by far, the stronger component in influencing commitment is the reflected image one has of the spouse's commitment" (Nock, 1995: 513). Here one's own thoughts about the marital state of being are demonstrated to impact the reality of the marriage.

Although these studies look at the idea of self-influenced marital happiness, they often explore it with the standard approach of determining the individual's marital happiness as caused by the spouse. Even in Myers and Booth's study on Marital Locus of Control, which investigates individual's perceptions of high and low levels of control over outcomes in marriage, the researchers ask about marital happiness based on the spouse's actions toward the self (1999: 427). This approach is ironic in such an 
exploration, because it seems to contradict the nature of the phenomenon being studied. Again, the current research stands in contrast to previous studies of self-influence on marital outconies, specifically marital happiness. Here the fundamental assumptions of the sources of marital happiness are shifted and the behavior of the respondent is used as a predictor of the respondent's marital happiness. This is done rather than drawing a causal link between the spouse's behavior and the respondent's feelings within the marriage, which summarizes the approaches taken by past research.

\section{Economic Resources}

Exploration of income or economic resources as variable in determining marital satisfaction indicates the possibility of higher rates of divorce and dissatisfaction for couples with lower incomes (Clark-Nicolas \& Gray-Little, 1991). Although objective measures of income and wealth are easier to obtain, perceived economic adequacy may be a more salient factor of marital happiness. One possible pathway for the influence of economic status on marital happiness is through loving/hostile behavior patterns. Conger et al. (1990) suggest that economic hardship could degrade marital quality by diminishing loving behaviors and increasing negative behavioral patterns. The study demonstrates that these findings are more robust for predicting the behavior of men than of women.

Asking about a combination of attitudes and behaviors should provide a sense of the level of altruism embraced by respondents in the context of their marriage relationships. Given the literature described, the following hypotheses were developed to guide this study. Fairness will not be an important predictor of marital happiness for men or for women. The willingness to serve one's spouse, even if gratitude is not expressed for the service rendered, will be a positive determining factor for marital happiness. By 
placing greater importance on their marriage and spouses' feelings than on their own position during a disagreement, individuals will experience greater marital happiness as a result. Loving communication with one's spouse on a regular basis, specifically expressions of love and gratitude for the spouse will influence the level of marital happiness reported. Individuals with an altruistic orientation in their marriages will demonstrate an understanding of the impact their own actions and attitudes have on the potential for happiness within the marriage relationship. In addition to these attitudes and behaviors that individuals can be asked about, factors exogenous to the marital relationship itself may also influence this model of marital happiness. For example, this research will explore the possibility that findings of the model are associated with certain socio-economic conditions, such as income level, as suggested by the literature. 


\section{METHODOLOGY}

\section{Operationalization of Variables}

After establishing an interest in the described influence of altruism on marital happiness, the Handbook of Family Measurement Techniques was searched for survey questions that could be used to gather data. Following a review of abstracts for the available tools that related to marriage intimacy, communication, etc., it was determined that the questions reflecting the existence of marital altruism and its relationship to marital happiness either did not exist or were unattainable. At that point a list of elements was composed of marital behaviors and attitudes that seemed to reflect altruism or lack thereof in marriage. This list was informed by casual observation, exposure to past survey instruments, and personal experience. Conceptually the questions were written to reflect elements of love including positive verbal communication, attitudes about power/compromise, perceptions of fairness, service, how a sense of marital happiness is derived, and primacy of concern and love for the spouse.

The measure of marital happiness used here is a modified version of one drawn from the Spanier Dyadic Scale (Spanier, 1976). Of the questions developed for this research, five ask the respondents to identify how strongly they agree or disagree with statements about marriage. These statements describe feelings and behaviors in marriage and require that respondents consider the needs and feelings of both themselves and their 
Independent variable: Spouse Determines Happiness (variable name $="$ spouse do")

3. My happiness in my marriage depends mainly on what my spouse does for me. (Number 3 reverse coded) Independent variable: Concede to Spouse (variable name="concede")

4. When I disagree with my spouse, I often concede that he/she might be right. Independent variable: Other-Interest in Conflict (variable name="conflict")

5. In a conflict over an issue with my spouse, I feel badly if we end up doing things his/her way.

(Number 5 reverse coded)

The following questions ask how often you do things in your marriage.

(Rarely or never $=1$, two or three times a month $=2$, about once week $=3$, a few times a week $=4$, almost every day $=5$, once a day or more $=6$ )

Independent variable name: Communicating Love (variable name="tell love")

6. How often do you tell your spouse that you love him/her?

Independent variable name: Communicating Gratitude (variable name="gratitude")

7. How often do you express gratitude to your spouse?

Income was measured as an ordinal variable, with four household income levels: $1=\$ 19,999$ or less per year, $2=\$ 20,000-59,999$ per year, $3=\$ 60,000-79,999$ per year, $4=\$ 80,000$ or greater per year.

Data

The data come from the 2004 Louisville Metropolitan Survey, conducted by the University of Louisville Department of Sociology. The telephone survey, conducted with a random dialing technique for household selection, involved 802 adults over age 18 
living in the metropolitan area of Louisville, KY. Only one individual in each household participated in the survey (with gender selection randomized). The survey was administered in the spring and early summer of 2004, with final data compilation in June 2004. Of the original sample of 802 participants, 425 identified themselves as being married, so they formed the subsample used for this research.

Analysis

Data were analyzed with SPSS 12.0 , a widely used software designed for survey data. For the present research purposes descriptive statistics, bivariate correlations, multiple regression, and factor analysis were generated. A path analysis model was also created to determine indirect effects of independent variables in the model. Because of interest in possible gender differences in the model, the dataset was split by sex for analysis. 


\section{RESULTS}

\section{Demographics}

With 425 out of 802 survey respondents reporting that they are married, the married sample represents $53 \%$ of the total sample. The 2000 Census data for Jefferson County reported $45.2 \%$ married couple families, out of total households. Compared to the statistical averages for the Louisville Metro, the married sample has a disproportionately high white percentage, with $87.1 \%$. The original complete sample (for married and non-married participants) is $81.4 \%$ white and $14.1 \%$ black compared with $77.4 \%$ white and $18.9 \%$ black for the area according to the 2000 Census. Minority representation in the married sample is slightly low for the Louisville metropolitan area with 9.2\% African American, and $2.4 \%$ other races. The ages in the sample population range from 20 to 90 years old, with the average age close to 51 and a standard deviation of 16 years. Forty-eight percent of the participants are male and $52 \%$ are female, which closely fits the census data of male $47.8 \%$, female $52.2 \%$.

Educational attainment ranges from eighth grade or less to holding an advanced degree. Only $3.3 \%$ of the sample have less than a high school education, with more than half the sample having received an associate's degree or higher. Over half of the sample are employed full-time (51.8\%), with 10\% working part-time, 19.3\% retired, and $12.5 \%$ described as homemakers. Students, disabled, unemployed, and otherwise unemployed 
persons comprise the remaining less than $7 \%$ of the sample. Income representation ranges from less than $5 \%$ reporting a household income under $\$ 20,000$ to $26.8 \%$ with income greater than $\$ 80,000$. Median married respondent income falls in the $\$ 60,000$ to $\$ 69,999$ range, with median income in the $\$ 50,000-59,999$ range for the total sample. This compares with a median household income of $\$ 39,457$ according to Jefferson County 2000 census data. Thus, the overall sample is slightly skewed toward a more wealthy, educated, and white population.

\section{Descriptive Statistics}

The independent variables exhibiting greatest gender differences in response distribution were "serve", "fair", and "income". For serving their spouses, men were most likely to report a willingness to serve without gratitude, with $47.5 \%$ very much agreeing with the statement and $41.7 \%$ somewhat agreeing. In contrast, $29 \%$ of women very much agreed with the statement and $38.5 \%$ somewhat agreed. Men were more likely to agree that the family workload was fairly divided with only $16 \%$ of men stating they very much disagreed that the workload was fairly divided, while $24 \%$ of women disagreed with the statement. As reported in the demographic statistics, men reported higher household incomes than women in the survey. Table 1 displays the descriptive statistics the independent and dependent variables, allowing for comparison of responses between men and women for all of the variables.

Bivariate correlations between the variables yielded some predictable results as well as a few surprising ones. The strongest correlation for men was between expressing love ("tell love") and expressing gratitude ("gratitude") $(r=.374, p=.000)$. Other significant correlations in the data for men were between "serve" and "concede" ( $r=199$, 
Table 1: DESCRIPTIVE STATISTICS

\begin{tabular}{|c|c|c|c|}
\hline VARIABLE & RESPONSE & $\%$ for MEN & $\%$ for WOMEN \\
\hline \multirow[t]{6}{*}{ Happy } & Very unhappy & 2.0 & 1.8 \\
\hline & Mostly unhappy & 1.0 & .9 \\
\hline & \multicolumn{2}{|c|}{ Mixed - equally happy and unhappy 6.5} & 8.3 \\
\hline & Mostly happy & 33.0 & 39.2 \\
\hline & Very happy & 57.5 & 49.8 \\
\hline & & Mean $=4.43$ & Mean $=4.34$ \\
\hline \multirow[t]{5}{*}{ Serve } & Very much disagree & 2.6 & 10.4 \\
\hline & Somewhat disagree & 4.1 & 19.0 \\
\hline & Somewhat agree & 43.6 & 40.3 \\
\hline & Very much agree & 49.7 & 30.3 \\
\hline & & Mean $=3.41$ & Mean $=2.91$ \\
\hline \multirow[t]{5}{*}{ Fair } & Very much disagree & 4.0 & 10.6 \\
\hline & Somewhat disagree & 12.6 & 13.9 \\
\hline & Somewhat agree & 30.2 & 26.4 \\
\hline & Very much agree & 53.3 & 49.1 \\
\hline & & Mean=3.33 & Mean=3.14 \\
\hline \multirow[t]{5}{*}{ Spouse do } & Very much agree & 4.6 & 3.3 \\
\hline & Somewhat agree & 12.2 & 10.2 \\
\hline & Somewhat disagree & 40.6 & 37.2 \\
\hline & Very much disagree & 42.6 & 49.3 \\
\hline & & Mean $=3.21$ & Mean $=3.33$ \\
\hline \multirow[t]{5}{*}{ Concede } & Very much disagree & 3.6 & 13.3 \\
\hline & Somewhat disagree & 7.8 & 20.0 \\
\hline & Somewhat agree & 56.8 & 47.6 \\
\hline & Very much agree & 31.8 & 19.0 \\
\hline & & Mean $=3.17$ & Mean $=2.72$ \\
\hline \multirow[t]{5}{*}{ Conflict } & Very much agree & 1.6 & 3.5 \\
\hline & Somewhat agree & 13.7 & 11.9 \\
\hline & Somewhat disagree & 52.1 & 58.9 \\
\hline & Very much disagree & 32.6 & 25.7 \\
\hline & & Mean=3.16 & Mean $=3.07$ \\
\hline \multirow[t]{7}{*}{ Tell love } & Rarely or never & 3.5 & 4.6 \\
\hline & Two or three times/month & 2.5 & 4.6 \\
\hline & About once a week & 6.0 & 7.4 \\
\hline & A few times a week & 13.4 & 9.7 \\
\hline & Almost every day & 16.4 & 10.6 \\
\hline & Once a day or more & 58.2 & 63.0 \\
\hline & & Mean=5.11 & Mean $=5.06$ \\
\hline \multirow[t]{7}{*}{ Gratitude } & Rarely or never & .5 & 1.4 \\
\hline & Two or three times/month & 1.5 & 7.8 \\
\hline & About once a week & 5.0 & 8.3 \\
\hline & A few times a week & 16.8 & 15.1 \\
\hline & Almost every day & 30.2 & 22.5 \\
\hline & Once a day or more & 46.0 & 45.0 \\
\hline & & Mean $=5.13$ & Mean $=4.84$ \\
\hline
\end{tabular}


$p=.006)$, "serve" and "tell love" ( $r=.222, p=.002)$, "spouse do" and "conflict" ( $r=.145$, $p=049)$, "spouse do" and "tell love" $(r=.174, p=.015)$, and "conflict" and "fair" ( $r=.151$, $\mathrm{p}=.038$ ). Two variables, "spouse do" and "gratitude" also approached significance in their correlation $\left(r=.137, p^{=} .055\right)$. Several of the variables were significantly related to marital happiness; "serve" and "happy" $(\mathrm{r}=.185, \mathrm{p}=.010)$, "concede" and "happy" $(\mathrm{r}=.224$, $p=.002)$, "conflict" and "happy" ( $r=.228, p=.002)$, and "tell love" and "happy" ( $r=.322$, $\mathrm{p}=.000$ ). In addition to those correlations, "gratitude" and "happy" approach significance in their correlation $(r=.123, p=.082)$. One notable lack of correlation occurred between the variables for "conflict" and "concede". Although both variables were significantly correlated with marital happiness for men in the data, they were not significantly related to one another $(r=.067, p=.372)$.

In the data for women, there were some similarities, with noticeable differences as well. The correlation between expressing love and expressing gratitude was much higher for women than for men $(r=.578, p=.000)$. Other variables with significant correlations were "serve" and "concede" $(\mathrm{r}=.315, \mathrm{p}=.000)$, "serve" and "tell love" $(\mathrm{r}=.153, \mathrm{p}=.027)$, "serve" and "gratitude" ( $r=.245, \mathrm{p}=.000)$, "fair" and "conflict" ( $\mathrm{r}=.237, \mathrm{p}=.001)$, "fair" and "tell love" ( $r=.185, p=.007)$, "fair" and "gratitude" $(r=.176, p=.010)$, "concede" and "gratitude" ( $r=.149, \mathrm{p}=.031)$, and "conflict" and "tell love" $(r=.140, \mathrm{p}=.048)$. Additionally, "fair" and "spouse do" $(r=-.128, \mathrm{p}=.063)$ and "spouse do" and "concede" $(\mathrm{r}=-.127, \mathrm{p}=.069)$ approached significance in their correlations. Four variables had significant correlations with marital happiness for women: "serve" and "happy" ( $r=149$, $\mathrm{p}=.031)$, "fair" and "happy" ( $r=.221, \mathrm{p}=.001)$, "tell love" and "happy" $(r=.275, \mathrm{p}=.000)$, 
and "gratitude" and "happy" $(r=.223, p=.001)$. These relationships were quite different than the previously described correlations for men.

\section{Regression}

Running a multiple regression on the data for both men and women together, with the seven independent marriage variables predicting marital happiness as the dependent variable, only two of the variables were found to have statistical significance and one additional variable approached significance. The overall model $R$-squared value was .147 and the level of significance for the model was .000 . Variables for race, income, education, and occupation were also tested, but none added significantly to the explanatory power of the multiple regression, so none of them were retained in the original model. Although as previously described, only one of the variables displayed a significant difference between men and women in terms of correlations, splitting the model by sex and performing the regression separately for men and women uncovered important differences. By dividing the model in that way two different models were created for men and women, with much higher predictive power than the combined model. In the end, the two regression models, presented in Tables 2 and 4 for men and Tables 3 and 5 for women, only shared one common independent variable, the measure for communicating love.

In the model for men, willingness to concede to their wives in a disagreement is predictive of marital happiness. Also tied to marital happiness for men is the reported ability not to feel badly about doing things the way their wives wish, specifically after a conflict over the issue. Neither one of these variables was found to have significance for predicting marital happiness for women. These results are somewhat surprising given the 
historic interpretations of gender influence on caring behavior, where women typically report behaving more empathetically than men to (Piliavin \& Charng, 1990). The variable "tell love", which asks about frequency of expressing tove, is a significant predictor of marital happiness for men.

Frequent expressions of love also predict marital happiness in the regression model for women, just as it does for men, although the relationship is stronger for women than it is for men. Perceived fairness in the distribution of the family workload relates significantly to marital happiness for women, but is an insignificant predictor for men. Although this does not support the hypothesis regarding fairness, it does reflect the findings in past literature. Two other variables that were significant predictors for marital Table 2 Hierarchical Regression of Marital Happiness for Men on the Independent Variables

\begin{tabular}{|c|c|c|c|}
\hline & B & Beta & R-square \\
\hline Constant & $2.017^{*}$ & & $.213^{*+k *}$ \\
\hline Tell love & $.224^{\star \star * *}$ & .349 & \\
\hline Concede & $.298^{* *}$ & .266 & \\
\hline Conflict & .105 & .089 & \\
\hline
\end{tabular}

* significant at the 0.05 level (2-tailed)

** significant at the 0.01 level (2-tailed)

**t significant at the 0.001 level (2-tailed)

Table 3 Hierarchical Regression of Marital Happiness for Women on the Independent Variables

\begin{tabular}{llll} 
& B & Beta & R-square \\
\hline Constant & $1.930^{* * *}$ & & $.245^{\text {*** }}$ \\
Serve & $.147^{\star}$ & .166 & \\
Fair & $.189^{* * *}$ & .249 & \\
Tell love & $.169^{* *}$ & .290 & \\
Income & $.185^{* *}$ & .228 &
\end{tabular}

"significant at the 0.05 level (2-tailed)

*t significant at the 0.01 level (2-tailed)

$* *$ significant at the 0.001 level (2-tailed) 
Table 4 Multiple Regression of Marital Happiness for Men on the Independent Variables

\begin{tabular}{lllc} 
& B & Beta & R-square \\
\hline Constant & $2.007^{\text {*** }}$ & & $.187^{\text {*** }}$ \\
Tell love & $.201^{\text {*** }}$ & .307 & \\
Concede & $.247^{\text {** }}$ & .211 & \\
Conflict & $.188^{*}$ & .158 & \\
\hline
\end{tabular}

* significant at the 0.05 level (2-tailed)

** significant at the 0.01 level (2-tailed)

*t*t significant at the 0.001 level (2-tailed)

Table 5 Multiple Regression for Women on the Independent Variables

\begin{tabular}{lllc}
\hline & B & Beta & R-square \\
\hline Constant & $2.331^{\text {***}}$ & & $.195^{\text {t**}}$ \\
Serve & $.144^{*}$ & .171 & \\
Fair & $.172^{\text {***}}$ & .228 & \\
Tell tove & $.137^{* *}$ & .246 & \\
Income & $.134^{* *}$ & .167 & \\
\hline
\end{tabular}

* significant at the 0.05 level (2-tailed)

** significant at the 0.01 level (2-tailed)

*n* significant at the 0.001 level (2-tailed)

happiness for women were the willingness to serve without gratitude and income, with both exhibiting a positive relationship with marital happiness. Income was not one of the variables originally intended to be a part of the model, however it was found to have significance for women. Surprisingly, the variable "serve" only achieved statistical significance in the multiple regression for women when the measurement for income was included as well.

Heirarchical regression justified selection of the most parsimonious models for both men and women, as inclusion of all the variables in addition to the statistically significant ones reduced the efficacy of the model. Overall model fit for women is 
indicated by an R-squared value of $.245, p=.000$ and for men the $R$-squared value was $.213, \mathrm{p}=.000$. The multiple regression for women from the parsimonious model with only the significant independent variables had an $R$-squared value of $.195, p=000$. For men, the parsimonious model had an $R$-squared value of $.187, p=.000$. The results of these models are displayed in Tables 4 and 5.

Income was not associated with marital happiness for men at all, which may be because men tended to report higher income levels than the women in the study. This could indicate that at lower levels of income, money has more of a direct effect on marital happiness. However, given all of the different findings for the way the variables performed for men and women, calculating interaction terms for each of the independent variables in the regression model revealed that only three gender differences hold statistical significance. "Concede", "income", and "fair" showed statistically significant gender differences for performance in the regression, where "concede" had a p-value of .014, "income" had a p-value of .021, and "fair" had a p-value of .051. Thus willingness to concede directly affects marital happiness for men but not for women, and higher levels of income are predictive of greater marital happiness for women but not for men. Factor Analysis

In order to understand the nature of the relationships between the seven independent variables asking about marriage, factor analysis was performed resulting in the formation of three distinct factors, with results displayed in Table 4 and Table 5. Income was excluded from the factor analysis, although it is used as an independent variable for women, because it does not fit conceptually with the other variables being analyzed. Because the variables were based on two different scales, the $\mathrm{z}$ scores were 
used to perform the factor analysis. The analysis method used was principle components analysis, with eigenvalues greater than one. The factors were orthogonally rotated using Varimax rotation, to obtain the optimal fit for the factors. The rotated loading scores were between .6 and .8 for all of the variables in each factor, for men and for women. The variables loaded in the same way for men and for women, with the only difference being the variance accounted for by each factor. For women, the first component was comprised of the variables "serve" and "concede", and it accounted for $28.3 \%$ of the shared variance. The second component included "spouse do", "tell love", and "gratitude" and it accounted for $18.8 \%$ of the shared variance. The third component for women included "fair" and "conflict" and it represented $16.3 \%$ of the variance. For men, the first component was comprised of the variables "spouse do", "tell love" and "gratitude", and it captured $23.9 \%$ of the total variance. The second component included "serve" and "concede" (the variables that were in the first component for women) and it

TABLE 6

\author{
FACTOR ANALYSIS FOR WOMEN \\ Using Standardized Scores for \\ Variables \\ Rotated Component Matrix
}

COMPONENT 1

$\%$ of Variance

Factor Loadings

Serve

Fair

Spouse do

Concede

$28.32 \%$

.774

Conflict

Tell love

Gratitude

Cronbach's Alpha

Bivariate Correlation $.315, p=.000$
COMPONENT 2

$18.88 \%$
COMPONENT 3

$16.31 \%$ 
TABLE 7

\section{FACTOR ANALYSIS FOR MEN \\ Using Standardized Scores for Variables \\ Rotated Component Matrix}

COMPONENT 1

$\%$ of Variance

$23.87 \%$

Factor Loadings

Serve

Fair

Spouse do

Concede

Conflict

Tell love

Gratitude

Cronbach's Alpha

Bivariate Correlation
COMPONENT 2

$16.88 \%$

.716

.676

.786

.687

.649

.422

-.-

$199, p=.006$
COMPONENT 3

$15.65 \%$

.804

.705
$151, p=.038$

contained $16.3 \%$ of the variance. The third component for men had the same variables as the third component for women, "fair" and "conflict", and it accounted for $15.6 \%$ of the variance. A Bartlett's test of sphericity indicated significance for both factor analyses, with a p-value of .000 , however the Kaiser-Meyer-Olkin measure of sampling adequacy was .566 for men and .580 for women, just failing to reach the desired minimum of .6 for factorability.

Path Analysis

A path analysis, with Figures 1 and 2 displaying the path diagrams, of the models for men and for women found indirect effects for several variables that were insignificant in the direct regression for the dependent variable. For women, "conflict" exerted an indirect influence on marital happiness through "fair" and "tell love". "Spouse do" had an effect through "fair" and "concede" had an effect through "serve". "Gratitude" had an indirect effect through three of the significant independent variables in the model: 
"serve", "tell love", and "fair". Also, "income" had an indirect effect through

"gratitude." Table 8 reports the direct and indirect effects for the all the variables in the path analysis for women. The path analysis accounted for each of the variables that were originally predicted to have a significant effect on marital happiness, although as discussed previously "income" was an additional variable of significance for women that did not factor into any of the models for men.

For men the variables with an indirect effect on the dependent variable were "gratitude", "serve", "spouse do", and "fair", displayed in Table 9. "Gratitude" had a mediated effect on happiness through "tell love". "Serve" had an effect through "tell love" and "concede", while "spouse do" had an influence through "tell love". "Fair" had an indirect effect through "conflict", thus all of the originally predicted independent variables were found to have significant indirect or direct effects on marital happiness for men. The path analysis for men shows fewer complicated interactions than the one for women, as well as smaller effects. As shown in comparison between Figures 1 and 2, the analysis for women depicts a combined total of 16 direct and indirect effects, while the one for men only contains eight such effects. Model fit was not calculated for the path diagrams, due to the regression analysis previously performed. Interaction terms from the regression reflect the statistical significance of the differences between men and women, showing that the most significant differences are for the variables measuring perceived fairness, willingness to concede to one's spouse, and income. 


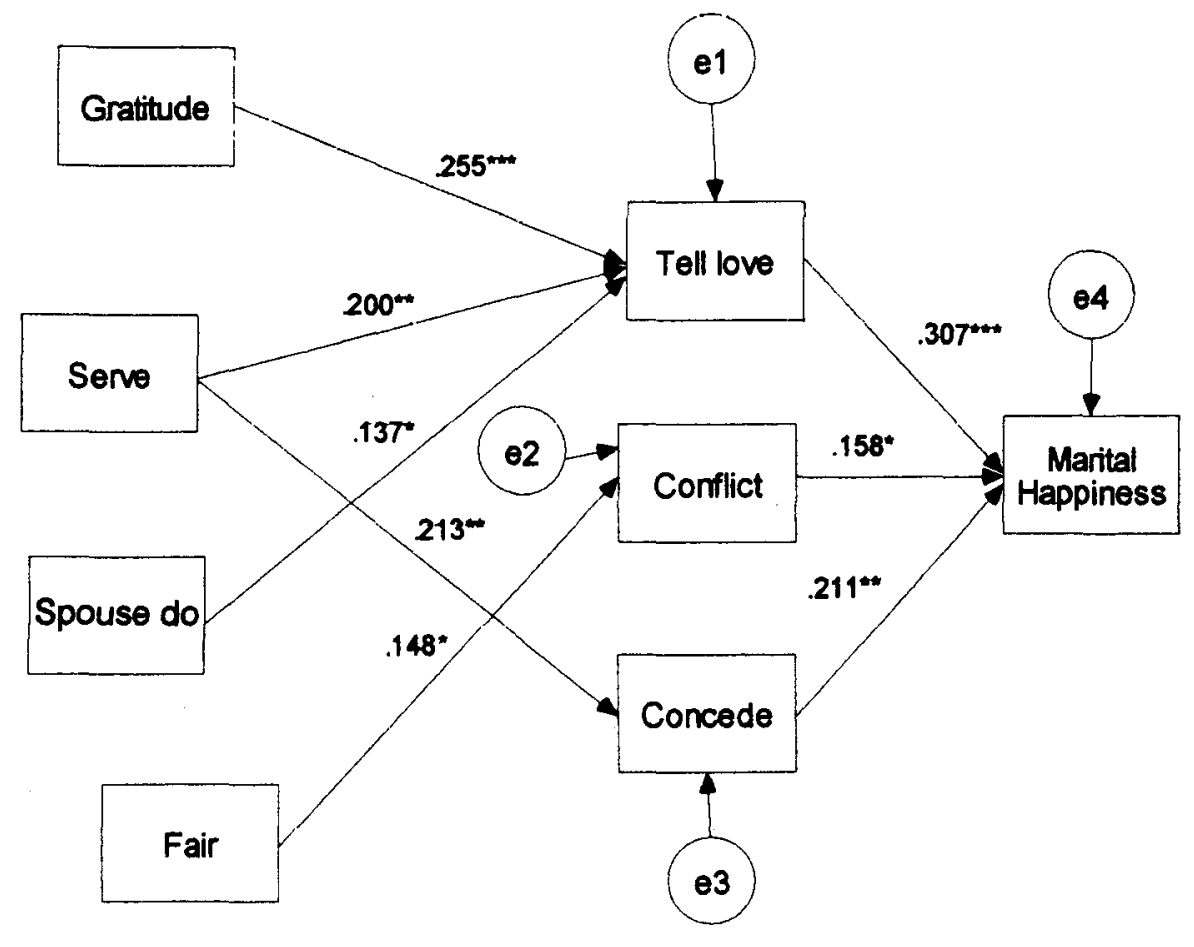

* coefficient is significant at the 0.05 level (2-tailed)

** coefficient is significant at the 0.01 level (2-tailed)

*** coefficient is significant at the 0.001 level (2-tailed)

Figure 1:

Path Analysis for Standardized Coefficients of Independent Variables Influencing the Outcome of Marital Happiness for Men 


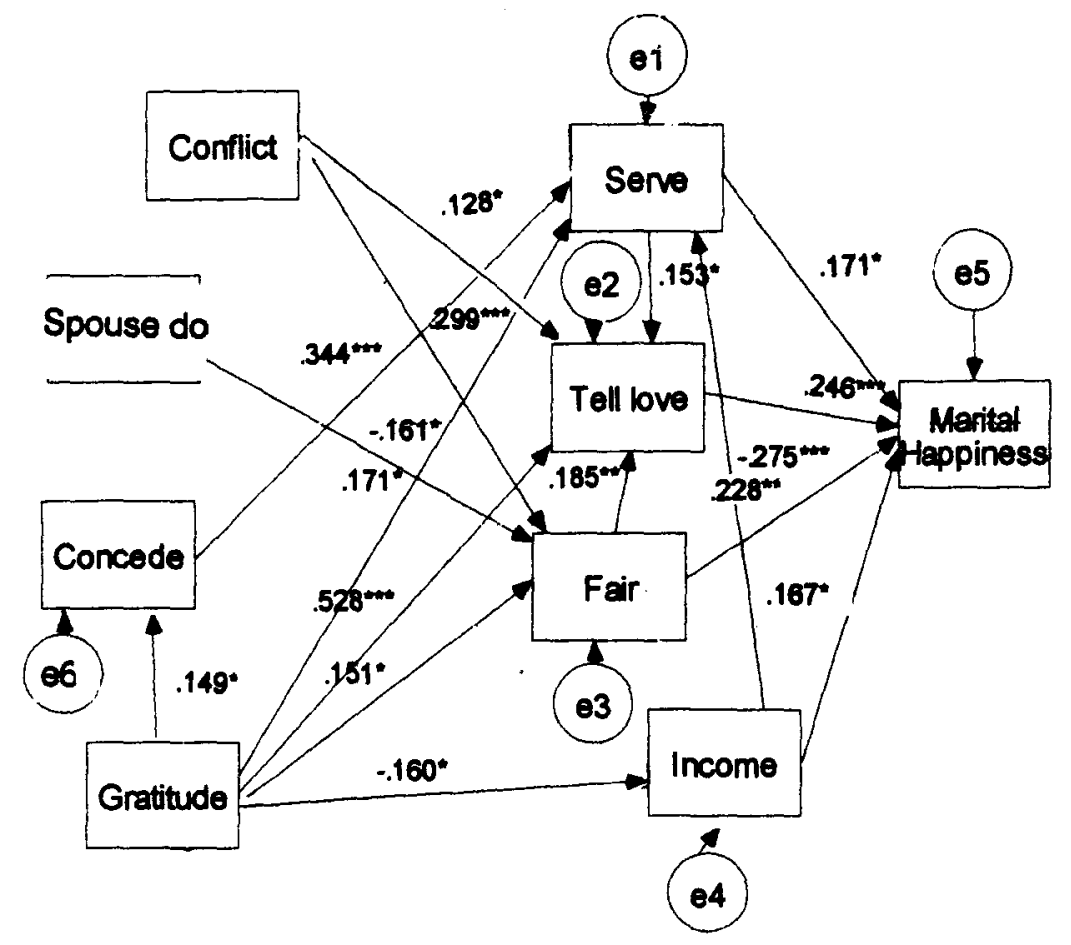

* coefficient is significant at the 0.05 level (2-tailed)

** coefficient is significant at the 0.01 level (2-tailed)

*** coefficient is significant at the 0.001 level (2-tailed)

Figure 2:

Path Analysis for Standardized Coefficients of Independent Variables Influencing the Outcome of Marital Happiness for Women 
TABLE 8

DIRECT AND INDIRECT EFFECTS ON MARITAL HAPPINESS FOR WOMEN

Using Standardized Regression Coefficients

\begin{tabular}{|c|c|c|c|}
\hline VARIABLE & DIRECT & INDIRECT & TOTAL \\
\hline \multirow[t]{4}{*}{ Conflict } & - & 0.031 (via tell love) & 0.031 \\
\hline & $(0 \%)$ & $(100 \%)$ & $(100 \%)$ \\
\hline & & 0.068 (via fair) & 0.068 \\
\hline & $(0 \%)$ & $(100 \%)$ & $(100 \%)$ \\
\hline \multirow[t]{2}{*}{ Concede } & - & 0.059 (via serve) & 0.059 \\
\hline & $(0 \%)$ & $(100 \%)$ & $(100 \%)$ \\
\hline \multirow[t]{2}{*}{ Spouse do } & --- & -0.037 (via fair) & -0.037 \\
\hline & $(0 \%)$ & $(100 \%)$ & $(100 \%)$ \\
\hline \multirow[t]{10}{*}{ Gratitude } & - & 0.029 (via serve) & 0.029 \\
\hline & $(0 \%)$ & $(100 \%)$ & $(100 \%)$ \\
\hline & & 0.130 (via tell love) & 0.130 \\
\hline & $(0 \%)$ & $(100 \%)$ & $(100 \%)$ \\
\hline & & 0.034 (via fair) & 0.034 \\
\hline & $(0 \%)$ & $(100 \%)$ & $(100 \%)$ \\
\hline & & -0.027 (via income) & -0.027 \\
\hline & $(0 \%)$ & $(100 \%)$ & $(100 \%)$ \\
\hline & & 0.009 (via concede, serve) & 0.009 \\
\hline & $(0 \%)$ & $(100 \%)$ & $(100 \%)$ \\
\hline \multirow[t]{2}{*}{ Serve } & $0.171^{\star}$ & 0.038 (via tell love) & 0.209 \\
\hline & $(82 \%)$ & $(18 \%)$ & $(100 \%)$ \\
\hline \multirow[t]{2}{*}{ Tell love } & $0.246^{\star \star \star}$ & - & 0.246 \\
\hline & $(100 \%)$ & $(0 \%)$ & $(100 \%)$ \\
\hline \multirow[t]{2}{*}{ Fair } & $0.228^{* *}$ & 0.046 (via tell love) & 0.274 \\
\hline & $(83 \%)$ & $(17 \%)$ & $(100 \%)$ \\
\hline \multirow[t]{2}{*}{ Income } & $0.167^{\star}$ & -0.047 (via serve) & 0.214 \\
\hline & $(78 \%)$ & $(22 \%)$ & $(100 \%)$ \\
\hline
\end{tabular}


TABLE 9

DIRECT AND INDIRECT EFFECTS ON MARITAL HAPPINESS FOR MEN

Using Standardized

Coefficients

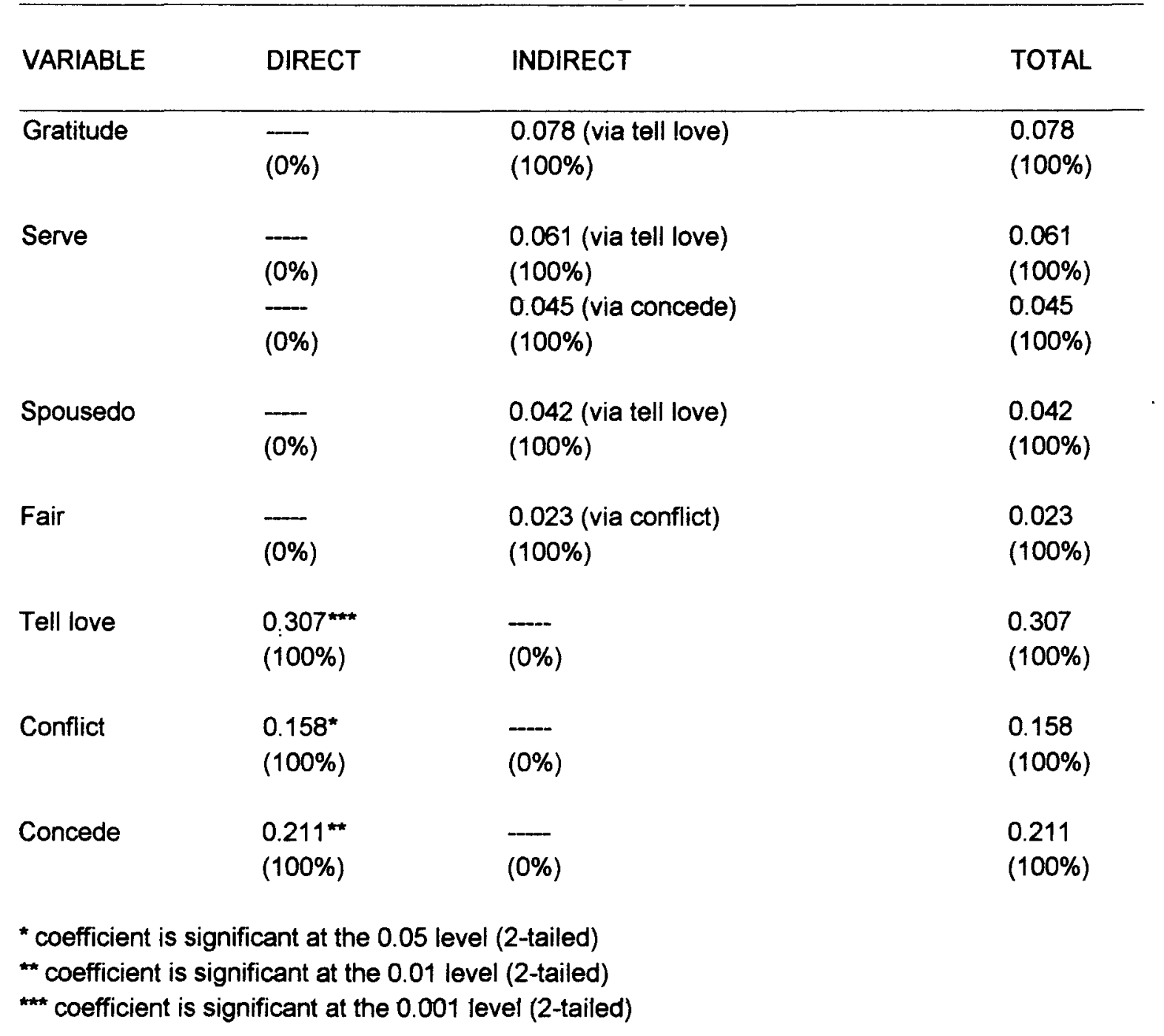




\section{DISCUSSION}

The results of the regression analysis demonstrate a link between altruistic attitudes and behaviors in marriage and the outcome of marital happiness. For men, the greatest influence on marital happiness came from expressing love. Conceptually these are linked, because frequent and sincere expressions of love should increase feelings of happiness in the marriage for both spouses. Also for men not feeling badly to go along with their wives' way of doing something after a conflict was predictive of marital happiness. This willingness to compromise indicates an ability to put the needs of the other and the marriage above one's own desire to be right in a conflict situation. Frequent concession that one's spouse may be right also predicted marital happiness for men. Each of these variable relationships are likely to be reciprocal in nature, since someone who experiences greater marital happiness may be more likely to exhibit loving and selfless behaviors within marriage.

For women, expressing love to their husbands was also the strongest predictor of marital happiness; the effect is greater for women than it is for men, however. Perceived fairness of workload distribution positively predicts marital happiness, which supports past literature findings that suggest this is a salient issue for married women. Surprisingly, willingness to selflessly serve one's spouse only became significant in the multiple regression after income was added to the analysis. The desire to serve, even in the absence of recognition for that service, seems strongly indicative of an altruistic 
orientation to marriage. This suggests that although fairness has an important relationship to marital happiness, women continue to display some elements of more traditional female attitudes. One way of interpreting the significance of income as a predictor for marital happiness for women is that higher income could affect marital happiness for women by decreasing chronic financial strains that cause conflict within the marriage. Again, just as in the regression for men, several of these relationships between variables are likely to be at least somewhat reciprocal in their causal pathways.

The path diagrams for men and women illustrate a number of effects between the variables in the study. For men gratitude influences expressions of love, which is an intuitive association, as both are forms of loving communication. The willingness to perform selfless service is also likely to indicate an increase in expressions of love. Also, this desire to serve one's spouse is associated with conceding that one's spouse may be right when views clash. Both of these variables are indicative of an ability to value one's spouse over one's own need to be right. For men the hypothesis that a spouse's actions do not determine one's own marital happiness is supported in an indirect fashion. A decrease in reported perception that what a spouse does creates marital happiness leads to increased expressions of love, which in turn correlates with marital happiness. Another indirect effect for men exists between fairness of workload and marital happiness, as mediated by the variable "conflict". For men, reporting a fair distribution of work ties to going along with a spouse's wishes after a conflict. The direct effects between independent variables and marital happiness were described in the regression discussion.

The multitude of connections between the endogenous and exogenous variables in the path diagram for women point to the cohesiveness of the concepts being measured. 
For women, increased willingness to demonstrate altruistic attitudes toward their husbands after a conflict over an issue predicts expression of love to husbands. The reported ability to not feel badly when following one's spouse's wishes after conflict also ties to faimess of worktoad for women. The link between these two variables also exists for men, however, the position in the diagram is reversed, with fairness having a direct effect on marital happiness for women, but not for men. Interestingly, for women reporting that one's spouse does not determine one's marital happiness is related to perception of the workload as less fairly distributed. Possibly, women who experience an unfair workload, but want to enjoy marital happiness have chosen to understand their marital happiness as being more influenced by their own behavior than that of their husbands. This would support the research hypothesis about fairness, spouse's actions, and marital happiness. In the path diagram for women, reported propensity for selfless service is associated with increased expressions of love. Women's perception of a fairly distributed workload also connects with telling husbands that they love them, since women who perceive more fair sharing of work are more likely to feel and express love.

Another relationship among variables in the model for women that is similar to the analysis for men is the association between willing to concede to the other and desire to serve in the absence of recognition for the service. Again, the order of the significance of the variables to the model was reversed for men and women, with conceding having an indirect effect on marital happiness for women. The expression of gratitude was linked for women with the willingness to selflessly serve. For women, gratitude influences conceding that one's spouse may be right in a disagreement and both variables are linked by an interest in the well-being of one's spouse. Gratitude was also linked with income, 
expression of love, and fairness for women. This indicates a complex relationship for women between experiencing gratitude and many other facets of married life. The association between gratitude and expression of love was the only one of these connections to exist for men as well as women.

The lack of direct connection between expression of gratitude and marital happiness was a surprising element of the study. Although an indirect influence through communication of love, as well as additional variables for women, was established between gratitude and marital happiness, this finding is surprising in light of the required maturity and selflessness inherent in frequent expressions of sincere gratitude toward one's spouse. Given the high correlation between expressing gratitude and expressing love, the lack of evidence from the data that gratitude directly affects personal marital happiness deserves further exploration. This facet of marital communication stands out not only because of its surprising role in this study, but as an important omission from the literature.

The relationships between income and two other variables for women were the only negative associations in the model. Interestingly, although income was positively related to marital happiness in the multiple regression for women, it has a negative effect on willingness to serve without recognition and expression of gratitude. This leads to a question of whether these manifestations of altruism are currently more strongly enacted by women of lower socio-economic status. Women of higher economic status may feel greater entitlement to reciprocal service within marriage. Although this research does not closely examine these relationships, this finding merits further investigation. 
Of the theoretical frameworks offered at the beginning of the paper, the feminist theory of gendered marital experience and those theories calling into question the inherent benefits of the influence of capitalism most closely support the findings. For example feminist studies have found that "'his' marriage continues to be better than 'hers.' Yet ... wives are not proportionately aggrieved" (Steil, 1997: xix). In the current study although women were slightly less likely to report high levels of marital happiness, they were significantly more likely to report an unfair distribution of the family workload. The evidence from this research suggests that although attaining high levels of marital happiness is more difficult for women in the absence of balanced housework sharing, some women find happiness in such a circumstance. Building on the feminist concept of empowerment, this research proposes that the choice to behave altruistically within one's marriage represents an alternative method of realizing power. Positive marital outcomes are associated with the experience of empowerment within marriage (Wilkes, Ferree, and Ratcliff, 1992). The present findings can be interpreted in such a light, in that power is based on freedom of choice and actions, a concept which the altruistic person understands in choosing to freely serve and love the other.

The current study developed different models for the relationships between marital attitudes and behaviors for men and women to reflect the gendered nature of the marriage experience. It was found that the manifestations of altruistic behavior in marriage work differently for men and women, however an altruistic orientation is important for both men and women in predicting marital happiness.

In accordance with an anti-capitalist sentiment, commodification and capitalism as applied to personal relationships would not be expected to produce happiness (Silver, 
1990). An extension of that idea is tested and supported in this paper, with the finding that altruistic marital behavior, the opposite of marital individualism as influenced by capitalism, is predictive of marital happiness. Where thie influence of capitalism does not exert influence on marital behavior through individualism, in other words in the presence of altruism, this study finds a link to greater marital happiness. One conflicting finding is the correlation between increased income and marital happiness. The method of measurement of income in the study limits the importance of this finding, since income is collapsed into only four categories, with the highest measuring household incomes greater than $\$ 80,000$.

The findings of this study confirm the established pattern of fairness as a more salient issue for women than for men in marriage. Symbolic interactionism provides one explanation of this state of mind for women as the result of changing societal perceptions of women's place in marriage. Fifty years ago a submissive and self-sacrificing wife/mother was assumed as the primary model for womanhood. This was complemented by an individualistic model of manhood, in which the husband arrived home after his long day at work knowing his needs would be taken care of by a pampering wife. Presumably the husband took care of the wife's financial needs and physical comforts through his employment and the rest of the family's concerns had claim on the attentions of the wife. Over the past fifty years, society has shifted away from this model of marital ideal, but in its place rests a model promoting dual individualism. Women have come to accept a new expectation that they will protect their own rights and needs within the marriage context, which often places them in conflict or competition with their husbands. 
Interestingly, in the study the men report greater willingness to serve without recognition, less concern about prevailing in a conflict, and greater willingness to concede that their wives are right. Men seem to understand that it is currently culturally desirable for them to at least appear to be sensitive and responsive to their wives. This finding is supported by Gottman et al. (1998) who report the correlation between husbands' acceptance of influence from their wives and higher relationship quality. At the same time, women have greater concern about the fair distribution of work in the family.

This study raises the question of how beneficial changes in expectations of marital behavior have been for women. It is proposed that women are currently more negatively affected by cultural influences toward individualism in their abilities to experience marital satisfaction. Such societal trends include calling into question the service and caring for others that many women offered within their marriages and families, as well as pressure for labor force participation as a primary means for achieving personal validation and satisfaction in life. Male behavior has been influenced by the individualistic tendencies of capitalist society for centuries following the Industrial Revolution; in contrast women as a group have only significantly experienced these influences within the past few decades.

Nancy Folbre quotes Virginia Held as suggesting "instead of importing into the household principles from the marketplace, perhaps we should export to the wider society the relations suitable for mothering persons and children" (Folbre, 2001: 20). The data from this study offer supporting evidence for that statement, given the lower mean of marital happiness for women in comparison with men. However one other way to 
interpret this finding rests on the idea that men and women vary in their abilities to accurately self-report their marital happiness. Sillars, Leonard, Roberts, and Dun (2002) note, "There was no correspondence between the husband's self-described communication and the observed behavior of husbands. Thus, the husbands in our sample lacked objective validation for the way they saw their own communication." (2002: 95). If such a phenomenon were occurring in this research, then the men would be reporting greater marital happiness than they are in fact experiencing. This was not a prevalent finding in the literature, but a possibility raised by the results of the cited study.

The results of the factor analysis showed the variables to be clustered in unexpected ways. Although the variable groupings did not occur in the expected manner, reflection on the factors produced reasonable underlying connections for the variables that loaded together. The first component included the variables for communicating love and gratitude and the variable for the spouse's actions determining one's marital happiness. The common thread among these variables seems to be a sense that one's own actions are significant to the marital relationship. The third variable "spouse do", represents the expectation that the spouse's actions have greater importance in determining the outcome of the relationship, while a respondent's own willingness to act positively by loving communication is demonstrated by the other two variables.

The second component includes "serve", the variable measuring enjoyment of service for one's spouse even if gratitude does not result and "concede", the variable gauging willingness to concede to one's spouse in a disagreement. The underlying concept that brings "serve" and "concede" together in this component is the selfless/other-focused orientation. Both of those variables suggest that the individual will 
place consideration of the spouse ahead of their own desires, even in less than ideal circumstances such as serving without recognition and conceding in a disagreement.

The third component encompasses the variables measuring fair distribution of workload and feeling wronged to do things the spouse's way in the wake of a conflict about an issue. These variables, "fair" and "conflict", seem to capture different angles on the element of give and take in the marriage. If work seems fairly distributed, then respondents were less likely to report feeling badly about going along with their spouses' ideas after a conflict.

Each of the relationships within the three components holds more strongly for women than it does for men. However, the components are the same for men and women, which is surprising given the difference between regression models based on gender. This indicates that even though the tests for factorability of the variables fell just short of significance, the components were probably accurately and meaningfully rendered, allowing for the possibility of insightful interpretation along those lines. Underlying elements in the way the variables group together for men and women are the same, which points to important fundamental similarities between males and females in spite of many other gender differences in the study.

\section{Limitations of the Study}

The limitations of the study include possible validity issues, the instrument design, social desirability bias affecting the data, and the administration of the survey to only one spouse in each couple.

The validity of the data is limited by how well the participants' interpretations of survey questions match the intended definitions. One study problem endemic to the field 
is the accuracy of the responses to the survey, given that even when the participants understand the intent of the research questions, social desirability is known to influence responses. The results of the marital happiness question appear to be skewed, for example, because such a high proportion of the respondents answered that they are "very happy." Similarly the validity of the variable that measures frequency of expressing love to the spouse is highly positively skewed. One possibility for further research is the development and use of a proxy for the marital happiness measure.

The variables examining communication of love and gratitude potentially lack explanatory power, because some couples use these expressions more reflexively than thoughtfully. Consequently, the exchanges seem to have lost the meaning and influence that can be derived from their use, as evidenced by correlations between of continued use of such expressions, even in the presence of maritaI unhappiness.

For future research several elements of the instrument would be reconstructed, in response to additional experience and understanding on my part. The statement used for the item on fairness would be adjusted, for example, so that it would be predicted to have a positive or negative impact on the model. One option for a replacement statement would be, "The distribution of the total family workload favors my spouse." This phrasing would offer a clear understanding of the participants' notions of fairness and work as related to the family. In contrast, the current wording offers no insight into the participants' perception of the direction of imbalance of fairness.

Without immediate feedback from the respondents, it is difficult or impossible to guess how they understood the instrument items. Given the range of meanings that can 
be associated with concepts being measured by the questions, it is safe to assume that some of the participants did not answer the questions as they were intended.

One of the most puzzling elements to consider for future research is the operationalization of marital happiness. One limitation of current research attempts is the individual way in which marital happiness is measured, where it could perhaps more accurately be reconceptualized as a dyadic property. While researchers have found that marital stability is a dyadic element of the marriage (Booth, 1991), such quantitative research has not been done on the concept of marital happiness or satisfaction. In his qualitative studies on marital happiness and altruism, Loveless (2000) examines the way in which couples experience and describe their marital happiness and interactions. $\mathrm{He}$ finds one couple with a truly reciprocally altruistic orientation, where the condition of marital happiness they experience could be described in terms of a "mutual level of marital joy."

A qualitative study on the marriages of happy couples that espouse altruistic love as their model may yield important understanding about the ways to quantitatively measure altruistic love and happiness in marriage. One advantage of a qualitative study in this context would be the greater likelihood of avoiding or identifying social desirability bias. The researcher would have access to information verbally offered by the couples, as well as the researcher's own observations of the couple. Another advantage of this tool would be the ability to ask the participants what elements of their marriage they have identified as being keys to marital happiness. Again, Hochschild's (1989) methods of study for Second Shift illustrate the richness of analysis and theory 
building available through intensive qualitative techniques, followed by thoughtful analysis. 


\section{CONCLUSION}

Although altruism has been avoided as an explanation for marital behavior and happiness by many in the social sciences, this study points to possibilities for its association with these outcomes. The finding that men and women exhibiting altruistic tendencies in their marriages did express high levels of marital satisfaction should be explored in other research attempts. The results of this study suggest that men and women enact marital altruism differently and these potential differences should be explored at greater length. By demonstrating the male experience with marital altruism, this research opens possibilities for new understandings of the typical male orientation within marriage. It also suggests that the female response to conflicting trends and expectations for the behavior of women in marriage is complex. In some respects the women in this study demonstrate a more guarded altruism than the men, and yet they also manifest many traditionally altruistic tendencies.

Great potential exists for the refinement of survey and interview instruments capable of uncovering motives and objectively identifying behavioral patterns in one of the most sensitive and important human relationships. Other facets of marital altruism should be incorporated into future research, including trust, mutual altruism, and the role of gratitude in marriage. Exploration of these topics would be enhanced by ethnographic and other qualitative research techniques. 
By shifting the way that researchers approach the study of marital happiness and its correlates, new avenues to understanding fundamental relational concepts unfold. The present paper represents a starting point for further research along these lines, in an effort to confirm the inherent caring for another that humans are capable of in their daily relations. 


\section{REFERENCES}

Ahlander, Nancy R. and Kathleen S. Bahr. 1995. "Beyond Drudgery, Power, and Equity: Toward an Expanded Discourse on the Moral Dimensions of Housework in Families." Journal of Marriage and the Family. 57, 1: 54-68.

Arnett, Jeffrey J. 1995. "Broad and Narrow Socialization: The Family in the Context of a Cultural Theory." Journal of Marriage and the Family. 57, 3: 617-628.

Bahr, Howard M. and Kathleen S. Bahr. 1996. "A Paradigm of Family Transcendence." Journal of Marriage and the Family. 58, 3: 541-555.

Bahr, Howard M. and Kathleen S. Bahr. 2001. "Families and Self-Sacrifice: Alternative Models and Meanings for Family Theory." Social Forces. 79, 4: 1231-1258.

Bahr, Stephen J., ed. 1991. Family Research: A Sixty-Year Review, 1930-1990. New York: Lexington Books.

Batson, C. Daniel and Laura L. Shaw. 1991. "Evidence for Altruism: Toward a Pluralism of Prosocial Motives." Psychological Inquiry. 2, 2: 107-122.

Bawin-Legros, Bernadette. 2004. "Intimacy and the New Sentimental Order." Current Sociology. 52, 2: 241-250.

Becker, Gary S, 1981. "Altruism in the Family and Selfishness in the Market Place." Economica. 48, 189: 1-15.

Becker, Gary S. 1991. A Treatise on the Family. Cambridge, Massachusetts: Harvard University Press.

Becker, Gary S. and Kevin M. Murphy. 2000. Social Economics: Market Behavior in a Social Environment. Cambridge, Massachusetts: The Belknap Press of Harvard University Press.

Bellah, Robert N., Richard Madsen, William M. Sullivan, Ann Swindler and Steven M. Tipton. 1996. Habits of the Heart: Individualism and Commitment in American Life. Updated Edition. Berkley: University of California Press.

Berscheid, Ellen. 1996. "The 'Paradigm of Family Transcendence': Not a Paradigm, Questionably Transcendent, but Valuable, Nonetheless." Journal of Marriage and the Family. 58, 3: 556-564. 
Berscheid, Ellen and W. Andrew Collins. 2000. "Who Cares? For Whom and When, How, and Why?" Psychological Inquiry. 11, 2: 107-110.

Berry, Wendell. 1990. What Are People For? San Francisco: North Point Press.

Bjornberg, Ulla. 2004. "Making Agreements and Managing Conflicts: Swedish DualEarner Couples in Theory and Practice." Current Sociology. 52, 1: 33-52.

Boss, Pauline G., William J. Doherty, Ralph LaRossa, Walter R. Schumm and Suzanne K. Steinmetz. 1993. Sourcebook of Family Theories an Methods: A Contextual Approach. New York: Plenum Press.

Bowman, Marilyn L. 1990. "Coping Efforts and Marital Satisfaction: Measuring Marital Coping and Its Correlates." Journal of Marriage and the Family. 52, 2: 463-474.

Bradbury, Thomas N., Frank D. Fincham and Steven R. H. Beach. 2000. "Research on the Nature and Determinants of Marital Satisfaction: A Decade in Review." Journal of Marriage and the Family. 62, 5: 964-980.

Browning, Don. 1997. "Self-Sacrifice, Self-Fulfillment, and Mutuality: The Evolution of Marriage." The Responsive Community. 8, 1: 58-62.

Buerkle, Jack V. and Robin F. Badgely. 1959. "Couple Role-Taking: The Yale Marital Interaction Battery." Marriage and Family Living. 21, 1: 53-58.

Buerkle, Jack V., Theodore R. Anderson and Robin F. Badgely. 1961. "Altruism, Role Conflict, and Marital Adjustment: A Factor Analysis of Marital Interaction." Marriage and Family Living. 23, 1: 20-26.

Burleson, Brant R. and Wayne H. Denton. 1997. "The Relationship between Communication Skill and Marital Satisfaction: Some Moderating Effects." Journal of Marriage and the Family. 59, 4: 884-902.

Burr, Wesley R. 1973. Theory Construction and the Sociology of the Family. New York: John Wiley \& Sons.

Cast, Alicia D. 2003. "Power and the Ability to Define the Situation." Social Psychology Quarterly. 66, 3: 185-201.

Clark, Margaret S., Steven Graham and Nancy Grote. 2002. "Bases for Giving Benefits in Marriage: What is Ideal? What is Realistic? What Really Happens?" Understanding Marriage. Ed. Patricia Noller and Judith A. Feeney. Cambridge: Cambridge University Press. 
Clark-Nicolas, Patricia, and Bernadette Gray-Little. 1991. "Effect of Economic Resources on Marital Quality in Black Married Couples." Journal of Marriage and the Family. 53, 3: 645-655.

Coltrane, Scott. 1997. "Scientific Half-Truths and Postmodem Parody in the Family Values Debate." Contemporary Sociology. 26, 1: 7-10.

Coltrane, Scott. 2000. "Research on Household Labor: Modeling and Measuring the Social Embeddedness of Routine Family Work." Journal of Marriage and the Family. 62, 5: 1208-1233.

Coltrane, Scott and Michele Adams. 2003. "The Social Constraction of the Divorce 'Problem': Morality, Child Victims, and the Politics of Gender." Family Relations. 52, 4: 363-372.

Conger, Rand D., Glen H. Elder, Jr., Frederick O. Lorenz, Katherine J. Conger, Ronald L. Simons, Les B. Whitbeck, Shirley Huck and Janet N. Melby. 1990. "Linking Economic Hardship to Marital Quality and Instability." Journal of Marriage and the Family. 52, 3: 643-656.

Cottingham, John. 1991. "The Ethics of Self-Concern." Ethics. 101, 4: 798-817.

Crittendon, Ann. 2001. The Price of Motherhood: Why the Most Important Job in the World Is Still the Least Valued. New York: Metropolitan Books.

Dempsey, Kenneth C. 1999. “Attempting to Explain Women's Perceptions of the Fairness of the Division of Housework." Journal of Family Studies. 5, 1: 3-24.

Dovidio, John F. 1991. "The Empathy-Altruism Hypothesis: Paradigm and Promise." Psychological Inquiry. 2, 2: 126-128.

Erickson, Rebecca J. 1993. "Reconceptualizing Family Work: The Effect of Emotion Work on Perceptions of Marital Quality." Journal of Marriage and the Family. $55,4: 888-900$.

Etzioni, Amitai. 1996. The New Golden Rule. New York: BasicBooks.

Everett, C. A., ed. 1992. Family Therapy Glossary. Washington, DC: The American Association for Marriage and Family Therapy.

Feldman, Harold and Martin E. Rand. 1965. "Egocentrism-Altercentrism in the Husband-Wife Relationship." Journal of Marriage and the Family. 27, 3: 386391 . 
Fincham, Frank D. and Thomas N. Bradbury. 1989. "Perceived Responsibility for Marital Events: Egocentric or Partner-centric Bias?" Journal of Marriage and the Family. 51, 1:27-35.

Finkenauer, Catrin and Wim Meeus. 2000. "How (Pro-)Social Is the Caring Motive?" Psychological Inquiry. 11, 2: 100-103.

Foa, Uriel G., John Converse, Jr., Kjell Y. Tornblom and Edna B. Foa, eds. 1993. Resource Theory: Explorations and Applications. New York: Academic Press, Inc.

Folbre, Nancy. 2001. The Invisible Heart: Economics and Family Values. New York: The New Press.

Gagne, Patricia. 2004. Lecture on Feminist Theory. University of Louisville, Sociology Department. Sociological Theory Seminar, Spring Semester.

Glenn, Norval D, and Charles N. Weaver. 1981. "The Contribution of Marital Happiness to Global Happiness." Journal of Marriage and the Family. 43, 1: 161-168.

Glenn, Norval D. 1990. "Quantitative Research on Marital Quality in the 1980's: A Critical Review." Journal of Marriage and the Family. 52, 4: 818-831.

Gottman, John M., James Coan, Sybil Carrere, and Catherine Swanson. 1998. "Predicting Marital Happiness and Stability from Newlywed Interactions." Journal of Marriage and the Family. 60, 1: 5-22.

Greenstein, Theodore N. 1996. "Gender Ideology and Perceptions of the Faimess of the Division of Household Labor: Effects on Marital Quality." Social Forces. 74, 3 : 1029-1042.

Hansen, Gary L. 1991. "Moral Reasoning and the Marital Exchange Relationship." Journal of Social Psychology. 131, 1: 71-81.

Heath, Melanie and Judith Stacey. 2002, "Review Essay: Transatlantic Family Travail." American Journal of Sociology. 108, 3: 658-668.

Heaton, Tim B. and Stan L. Albrecht. 1991. "Stable Unhappy Marriages." Journal of Marriage and the Family. 53, 3: 747-758.

Hechter, Michael and Satoshi Kanazawa. 1997, "Sociological Rational Choice Theory." Annual Review of Sociology. 23, 191-214.

Hochschild, Arlie R. 1983. The Managed Heart: Commercialization of Human Feeling. Berkley: University of California Press. 
Hochschilild, Arlie R. 1989. The Second Shift. New York: Avon.

Honeycutt, James M. 1986. "A Model of Marital Functioning Based on an Attraction Paradigm and Social-Penetration Dimensions." Journal of Marriage and the Family. 48, 3: 651-659.

Horkheimer, Max and Theodor W. Adorno. 1972. Dialectic of Enlightenment. Translated by John Cumming. New York: Herder and Herder.

Huston, Ted L. 2000. "The Social Ecology of Marriage and Other Intimate Unions." Journal of Marriage and the Family. 62, 2: 298-320.

Jeffries, Vincent. 2000. "Virtue and Marital Conflict: A Theoretical Formulation and Research Agenda." Sociological Perspectives. 43, 2: 231-246.

Johnson, David R., Teodora O. Amoloza and Alan Booth. 1992. "Stability and Developmental Change in Marital Quality: A Three-Wave Panel Analysis." Journal of Marriage and the Family. 54, 3: 582-594.

Johnson, David R. and Alan Booth. 1998. "Marital Quality: A Product of the Dyadic Environment or Individual Factors?" Social Forces. 76, 3: 883-904.

Kalmijn, Matthijs. 1999. "Father Involvement in Childrearing and the Perceived Stability of Marriage." Journal of Marriage and the Family. 61, 2: 409-421.

Kellenberger, J. 1995. Relationship Morality. University Park, Pennsylvania: The Pennsylvania State University Press.

Kendrick, Douglas T. 1991. "Proximate Altruism and Ultimate Selfishness." Psychological Inquiry. 2, 2: 135-137.

Kleingeld, Pauline. 1998. "Just Love? Marriage and the Question of Justice." Social Theory \& Practice. 24, 2: 261-281.

Kim, Jungsik and Elaine Hatfield. 2004. "Love Types and Subjective Well-Being: A Cross-Cultural Study." Social Behavior and Personality. 32, 2: 173-182.

Korsgaard, Christine M. 1992. "Creating the Kingdom of Ends: Reciprocity and Responsibility in Personal Relations." Philosophical Perspectives. 6: 305-332.

Krebs, Dennis L. 1991. “Altruism and Egoism: A False Dichotomy?” Psychological Inquiry. 2, 2: 137-139. 
Lennon, Mary C. and Sarah Rosenfield. 1994. "Relative Fairness and the Division of Housework: The Importance of Options." The American Journal of Sociology. 100, 2: 506-531.

Levinger, G. 1965. "Altruism in Marriage: A Test of the Buerkle-Badgley Battery." Journal of Marriage and the Family. 27, 1:32-33.

Loveless, A. Scott. 1999. "Choosing Our Own Unhappiness: What Leo Tolstoy Has to Say About Getting Along in Our Close Relationships." Meridian Magazine (Online). March 26, 1999. Available: meridianmagazine.com/archives.

Loveless, A. Scott. 2000. "Paired Conceptions of Morality and Happiness as Factors in Marital Happiness." Dissertation. Brigham Young University.

Margolis, Howard. 1982. Selfishness, Altruism, and Rationality: A Theory of Social Choice. New York: Cambridge University Press.

McAdams, Dan P. 2000. “Attachment, Intimacy, and Generativity." Psychological Inquiry. 11, 2: 117-120.

McVeigh, Frank J. 2000. “Today's Changing Values in Marriage and the Family: A Communitarian Perspective." Sociological Viewpoints. 16, Fall: 10-31.

Milardo, Robert M. and Steve Duck, eds. 2000. Families as Relationships. New York: John Wiley \& Sons, Ltd.

Monroe, Kristen R. 1996. The Heart of Altruism: Perceptions of a Common Humanity. Princeton: Princeton University Press.

Mook, Douglas G. 1991. "Why Can’t Altruism Be Selfish?” Psychological Inquiry. 2, 2: $139-140$.

Myers, Scott M. and Alan Booth. 1999. "Marital Strains and Marital Quality: The Role of High and Low Locus of Control." Journal of Marriage and the Family. 61, 2: 423-436.

Nichols, M. P., and R. C. Schwartz. 1998. Family Therapy: Concepts and Methods. Boston: Allyn \& Bacon.

Nock, Steven L. 1995. “Commitment and Dependency in Marriage." Journal of Marriage and the Family. 57, 2: 503-514.

Parducci, Allen. 1995. Happiness, Pleasure, and Judgement: The Contextual Theory and Its Applications. Mahweh, New Jersey: Lawrence Erlbaum Associates, Publishers. 
Paul, Ellen F., Fred D. Miller, Jr. and Jeffrey Paul, eds. 1997. Cambridge: Cambridge University Press.

Piliavin, Jane A. and Hong-Wen Charng. 1990. "Altruism: A Review of Recent Theory and Research." Annual Review of Sociology. 16: 27-65.

Pina, Darlene L. and Vern L. Bengston. 1993. "The Division of Household Labor and Wives' Happiness: Ideology, Employment, and Perceptions of Support." Journal of Marriage and the Family. 55, 4: 901-912.

Post, Stephen G., Lynn G. Underwood, Jeffrey P. Schloss and William B. Hurlbut. 2002. Altruism and Altruistic Love: Science, Philosophy, and Religion in Dialogue. Oxford: University Press.

Quinn, Naomi. 1996. "Culture and Contradiction: The Case of Americans Reasoning about Marriage." Ethos. 24, 3: 391-425.

Richard, Alan J. 2000. "Caregiving: The Forgotten Element in Attachment." Psychological Inquiry. 11, 2: 69-81.

Risch, G. S., L. A. Riley and M. G. Lawler. 2003. "Problematic Issues in the Early Years of Marriage: Content for Premarital Education." Journal of Psychology and Theology. 31: 253-269.

Ritzer, G. and D. Goodman. 2004. Modern Sociological Theory. $6^{\text {th }}$ Edition. Boston: McGraw-Hill.

Rogers, Stacy J. 1996. "Mothers' Work Hours and Marital Quality: Variations by Family Structure and Family Size." Journal of Marriage and the Family. 58, 3: 606-617.

Rogers, Stacy J. and Paul J. Amato. 2000. "Have Changes in Gender Relations Affected Marital Quality?" Social Forces. 79, 2: 731-753.

Sanchez, Laura. 1996. "Feminism, Family Work, and Moral Discourse: A Comment on Ahlander and Bahr's 'Beyond Drudgery, Power, and Equity."' Journal of Marriage and the Family. 58, 2: 514-525.

Scanzoni, John. 2000. Designing Families: The Search for Self and Community in the Information Age. Thousand Oaks: Pine Forge Press.

Schluterman, Julie A, 2001. "The Role of Marital Satisfaction in Americans' Overall Life Satisfaction." Southern Sociological Society. Conference Paper. 
Schoen, Robert, Nan Marie Astone, Kendra Rothert, Nicola J. Standish and Young J. Kim. 2002. "Women's Employment, Marital Happiness, and Divorce." Social Forces. 81, 2: 643-662.

Shehan, C. L., M. A. Burg, and C. A. Rexroat. 1986. "Depression and the Social Dimensions of the Fulltime Housewife Role." Sociological Quarterly. 27: 403421.

Silver, Allan. 1990. "Friendship in Commercial Society: Eighteenth-Century Social Theory and Modern Sociology." The American Journal of Sociology. 95, 6: 1474-1504.

Simon, Robin W. 1997. "The Meaning Individuals Attach to Role Identities and Their Implications for Mental Health." Journal of Health and Social Behavior. 38, 3: 256-274.

Sorokin, Pitrim A. 1950. Explorations in Altruistic Love and Behavior. Boston: The Beacon Press.

Spanier, G. B. 1976. "Measuring Dyadic Adjustment: New Scales for Assessing the Quality of Marriage and Similar Dyads." Journal of Marriage and the Family. 31, 2: 15-28.

Steil, Janice M. 1997. Marital Equality: Its Relationship to the Well-Being of Husbands and Wives. Thousand Oaks: Sage Publications.

Stevens, Daphne, Gary Kiger and Pamela J. Riley. 2001. "Working Hard and Hardly Working: Domestic Labor and Marital Satisfaction Among Dual-Earner Couples." Journal of Marriage and the Family. 63, 2: 514-526.

Suitor, J. Jill. 1991. "Marital Quality and Satisfaction with the Division of Household Labor across the Family Life Cycle." Journal of Marriage and the Family. 53, 1: 221-230.

Tabachnick, Barbara G. and Linda S. Fidell. 2001. Using Multivariate Statistics. $4^{\text {th }}$ edition. New York: Harper Collins College Publishers.

Thomas, Veronica G. 1990. "Determinants of Global Life Happiness and Marital Happiness in Dual-Career Black Couples." Family Relations. 39, 2: 174-178.

Thompson, Linda. 1993. "Conceptualizing Gender in Marriage: The Case of Marital Care." Journal of Marriage and the Family. 55, 3: 557-569.

Touliatos, John, Barry F. Perlmutter, and Murray A. Straus, eds. 1990. Handbook of Family Measurement Techniques. Newbury Park: Sage Publications. 
Tourangeau, Roger, Kenneth A. Rasinki and Norman Bradburn. 1991. "Measuring Happiness in Survey: A Test of the Subtraction Hypothesis." The Public Opinion Quarterly. 55, 2: 255-266.

Tronto, Joan C. 1993. Moral Boundaries: A Political Argument for an Ethic of Care. New York: Routledge.

Van Praag, Bernard, and Ada Ferrier-I-Carbonell. 2001. Happiness Quantifies. Oxford: University Press.

Vangelisti, Anita L., ed. 2004. Handbook of Family Communication. Mahweh, New Jersey: Lawrence Erlbaum Associates.

Velleman, J. David. 1999. “Love as Moral Emotion.” Ethics. 109, 2: 338-374.

Voydanoff, Patricia and Brenda W. Donnelly. 1999. "The Intersection of Time in Activities and Perceived Unfairness in Relation to Psychological Distress and Marital Quality." Journal of Marriage and the Family. 61, 3: 739-751.

Wall, John, Thomas Needham, Don S. Browning and Susan James. 1999. "The Ethics of Relationality: The Moral Views of Therapists Engaged in Marital and Family Therapy." Family Relations. 48, 2: 139-149.

Wallach, Michael A. and Lise Wallach. 1990. Rethinking Goodness. Albany: State University of New York Press.

Warner, C. Terry and Terrance D. Olson. 1981. "Another View of Family Conflict and Family Wholeness." Family Relations. 30, 4: 493-503.

Warner, C. Terry. 2001. The Bonds that Make Us Free: Healing Our Relationships, Coming to Ourselves. Salt Lake City: Shadow Mountain.

Webster, Pamela S., Terry L. Orbuch and James S. House. 1995. "Effects of Childhood Family Background on Adult Marital Quality and Perceived Stability." The American Journal of Sociology. 101, 2: 404-432.

White, James M. and David M. Klein. 2002. Family Theories. $2^{\text {nd }}$ edition. Thousand Oaks: Sage Publications.

Wilkie, Jane R., Myra M. Ferree and Kathryn S. Ratcliff. 1998. "Gender and Fairness: Marital Satisfaction in Two-Earner Couples." Journal of Marriage and the Family. 60, 3: 577-594.

Wilson, James Q. 1997. The Moral Sense. New York. Simon \& Schuster. 
Winfield, Richard D. 1998. The Just Family. Albany: The State University of New York Press.

Wood, Julia T. 1994. Who Cares? Women, Care, and Culture. Carbondale, Illinois: Southern Illinois University Press.

Wright, Debra L. and William S. Aquilino. "Influence of Emotional Support Exchange in Marriage on Caregiving Wives' Burden and Marital Satisfaction." Family Relations. 47, 2: 195-204.

Youngstrom, Eric. 2000. "Do We Need to Invent Another Emotion? The Role of Caring in Attachment." Psychological Inquiry. 11, 2: 103-107.

Zaretsky, Eli. 1986. Capitalism, the Family, and Personal Life. Revised and Expanded Edition. New York: Harper \& Row, Publishers.

Zolot, Amy L. 2000. “The Interpersonal Processes of Care and Social Support in Heterosexual Mid-Life Couples: An Investigation of Symbolic Meanings, and Interpretations of Normative Marital Interactions." Dissertation Abstracts International, A: The Humanities and Social Sciences. 60, 9: 3546-A.

Zuo, Jiping. 1992. "The Reciprocal Relationship Between Marital Interaction and Marital Happiness: A Three-Wave Study." Journal of Marriage and the Family. 54, 4: 870-878. 


\section{CURRICULUM VITAE}

NAME: $\quad$ Natalie Jane Brinton Call

ADDRESS: 2911 Abigail Dr. \#4

Louisville, KY 40205

DOB: $\quad$ Durham, North Carolina - August 7, 1978

EDUCATION

\& TRAINING: $\quad$ B.S., Sociology

Brigham Young University

1996-2000

AWARDS: National Merit Scholarship

1996 